\title{
The Emergence of Dynamic Contract Law
}

\author{
Melvin Aron Eisenberg $\dagger$
}

\section{TABLE OF CONTENTS}

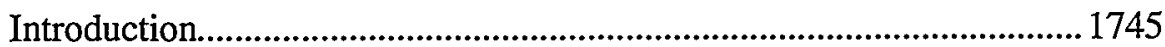

I. The Nature of Contract-Law Reasoning .............................................1750

II. The Emergence of Individualized and Subjective Principles of

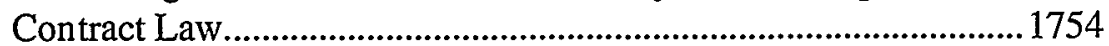

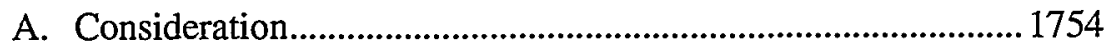

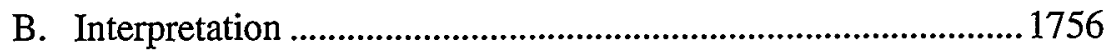

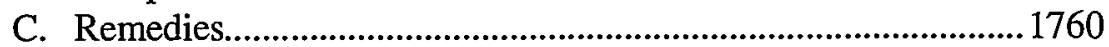

1. Market-price measures of damages......................................1760

2. Specific performance ..............................................................1761

III. The Emergence of Dynamic Principles of Contract Law ..................1762

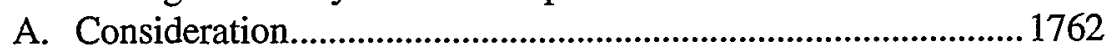

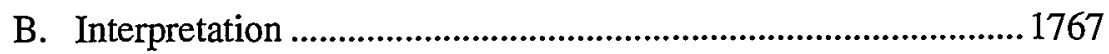

1. Conduct before the time of contract formation.....................1767

2. Conduct after the time of contract formation ........................1770

C. Remedies-The Principle of Hadley v. Baxendale .....................1771

D. Liquidated Damages ....................................................................1779

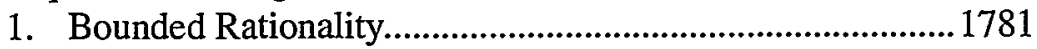

2. Irrational disposition .............................................................1782

3. Defective Capability..............................................................1782

E. The Excuse of Express Conditions ..............................................1789

F. Offer and Acceptance; the Duty to Negotiate in Good Faith .... 1794

1. Classical contract law ........................................................ 1794

a. Preliminary negotiations...................................................1794

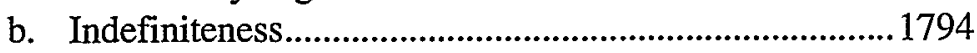

Copyright $\odot 2000$ California Law Review, Inc. California Law Review, Incorporated (CLR) is a California nonprofit corporation. CLR and the authors are solely responsible for the content of their publications.

$\div \quad$ Koret Professor of Law, School of Law, University of California, Berkeley (Boalt Hall). A.B. Columbia College 1956; LL.B. Harvard Law School 1959. This Essay was originally given as a paper at the International Conference on Contemporary Legal Scholarship: Achievements and Prospects, which was organized by The Cegla Law Institute for Comparative and Private International Law, and held at Tel-Aviv University in December 1999. I thank the participants at that Conference for their valuable comments. I also thank Pilar Sansone for her excellent research assistance. 
c. Further-document-to-follow 1795

d. Gaps 1795

e. Agreements to agree and the duty to negotiate in good faith 1796

2. Modern contract law 1796

a. Cases involving an explicit agreement concerning the conduct of negotiations.

b. Cases in which there is an implicit agreement to negotiate in good faith

c. Cases in which a party's conduct results in the imposition of a duty to negotiate in good faith

Conclusion 


\title{
The Emergence of Dynamic Contract Law
}

\author{
Melvin Aron Eisenberg
}

\section{INTRODUCTION}

This Essay has a normative thesis and a positive thesis. The normative thesis is that contract law reasoning should be substantive rather than formal, and that the rules of contract law should, where appropriate, be individualized rather than standardized, subjective rather than objective, complex rather than binary, and dynamic rather than static. The positive thesis is that the twentieth century witnessed the emergence of contract law reasoning, and contract law rules, with just those characteristics.

I will call the normative principle that instructs us how to make the best possible rules of contract law the basic contracts principle. This principle has two branches. The first branch describes the content that contract law should have. The second branch describes the manner in which that content should be determined. The two branches are related, because the content that contract law should have depends in part on how that content should be determined.

The basic contracts principle is as follows:

First, if but only if appropriate conditions are satisfied, and subject to appropriate constraints, contract law should effectuate the objectives of parties to a promissory transaction.

Second, the rules that determine the conditions to, and the constraints on, the legal effectuation of the objectives of parties to promissory transactions, and the manner in which those objectives are ascertained, should consist of the rules that would be made by a fully informed legislator who seeks to make the best possible rules of contract law by taking into account all relevant propositions of morality, policy, and experience (the Legislator). When more than one such proposition is relevant, the Legislator should exercise good judgment to give each proposition proper weight, and to either subordinate some propositions to others, or craft a rule that is the best vector of the propositions, considering their relative weights and the extent to which an accommodation can be fashioned that reflects those relative weights to the fullest practicable extent.

The Legislator, rather than the judge, plays the central role in the basic contracts principle because a legislator, unlike a judge, is free from an obligation to follow existing doctrine. Because the Legislator is not bound 
by existing doctrinal propositions, but instead is an author of such propositions and can re-author them at any time, his only concern is that doctrinal propositions properly reflect moral, policy, and empirical propositions.

That the basic contracts principle depends on the rules the Legislator would make does not mean that contract law should be made by the legislature. The theory of contracts-in particular, the theory of the best content of contract law - must be distinguished from institutional theory, which addresses such issues as what are the best institutions to make different kinds of legal rules, how should those institutions be structured to that end, and to what constraints should those institutions be subject. Because of institutional constraints, any given body of law at any given moment of time may not have the best content it should have over the long run. For example, one of the constraints on courts is that they must attend to the interest of doctrinal stability, especially, although not exclusively, because courts act retrospectively. As a result of this constraint, the courts may for periods of time follow rules that are not the rules that would be best if the interest of doctrinal stability were put to one side. Similarly, and to the same effect, courts are not institutionally free to consider all relevant and meritorious social propositions, but instead are normally confined to those social propositions that have substantial social support.

It is for just these reasons that the central figure in the basic contracts principle is the Legislator, not the courts. However, a legislature is also subject to institutional constraints that may lead it to adopt rules that are not the best rules, even if the legislature is disinterested and fully informed. For example, although the legislature normally acts prospectively, and can ameliorate the problems raised by transition costs in various ways, there are nevertheless good institutional reasons why a legislature would take transition costs into account. More fundamentally, there are good institutional reasons, which need not be rehearsed here, why a legislature would allow the courts to develop certain bodies of law, including the body of contract law.

Accordingly, the central role played by the Legislator in the basic contracts principle does not require that the legislature instantly adopt the best rule of contract law, or even that contract law should be made by the legislature. That does not mean the central role played by the Legislator in the basic contracts principle serves no function. Because the Legislator, unlike a legislature, is free of institutional constraints in determining the best content of contract law, giving pride of place to the Legislator instructs all members of the profession how to generate that content. Over the short run, that instruction is more likely to be carried out by academic members of the profession than by legislators or courts, but this does not limit the power of the instruction over the long run. 
To put this differently, the theory of contract law is the theory of the best content of contract law over the long run, not the theory of what contract law should be at any moment of time when institutional constraints are taken into account.

The basic contracts principle may seem innocuous. Indeed, it may look incontestable, and therefore not a principle at all. In fact, however, the principle and its implications explicitly or implicitly reject a number of strongly held positions. For example:

- The basic contracts principle rejects single-value theories of contract, such as autonomy theories, and instead accepts inultiple values and even conflicting values. Part of the human moral condition is that we hold many proper values, some of which will conflict in given cases. Part of the human social condition is that many values are relevant to the creation of a good world, some of which will conflict in given cases. Contract law should not attempt to escape these moral and social conditions. In contract law, as in life, all meritorious values should be taken into account, even if those values may sometimes conflict.

- The basic contracts principle rejects the position, most closely associated with relational contract theory, but also with the works of others, such as Atiyah, that contract law is not, or ought not be, promise based. ${ }^{1}$ Under the first branch of the principle, contract law normally does not get off the ground unless a party has used an expression that is or can fairly be interpreted to be a promise, or at least has engaged in a transaction that is set in a promissory matrix. At the same time, the principle rejects the concept that the only parameter of contract law is to effectuate the objectives of parties to a promissory transaction. Under the principle, promises are to be enforced only under appropriate conditions and only subject to appropriate constraints.

- The basic contracts principle deemphasizes the role of contract law in providing efficient incentives to contracting parties. Under the principle, the purpose of contract law should be to effectuate the objectives of parties to promissory transactions, not to lead them into acting efficiently. Contract law rules are often unlikely to have much of an incentive effect, because inost contracting parties do not know contract law. Furthermore, contracting parties do not need incentives to act efficiently. They normally will act efficiently in their own self-interest.

- The basic contracts principle rejects the position that contract law should always assume that contracting parties are perfectly rational. Cognitive psychology tells us that this is not so. Under the basic contracts principle, contract law should be based on the teachings of experience concerning how people act.

1. See P. Atiyah, The Rise and Fald, of Freedom of Contract 1-7, 754-64 (1979); Ian R. MacNeil, Relational Contract Theory: Challenges and Queries, 94 Nw. U. L. Rev. 877 (2000); William C. Whitford, Ian MacNeil's Contribution to Contracts Scholarship, 1985 Wisc. L. REv. 545. 
- The basic contracts principle rejects formalism, in two critical respects. First, the principle rejects the form of writing as dispositive. The objective of contract law should be to effectuate the intent of the contracting parties, not to effectuate a writing. While a writing is entitled to significant weight, it must always be seen in the context in which it is embedded and in light of the behavior of the parties both before and after the writing. To put this differently, the text of a contract is not simply the writing, if there is one, but also such elements as custom, usage, the parties' negotiations, their course of dealing in prior contracts, and their course of performance. Second, the principle rejects the desirability, and indeed even the coherence, of formal legal reasoning. Rather, the principle takes the position that all legal reasoning must be substantive; that is, legal reasoning must take into account policy, morality, and experience.

Contract law doctrines can be ranged along various spectra. One of these spectra runs from the pole of objectivity to the pole of subjectivity. A contract law doctrine lies at the objective pole if its application depends on a directly observable state of the world, and at the subjective pole if its application depends on a mental state. For example, application of the plainmeaning rule of interpretation depends on a determination of observable meanings attached to words by established communities. In contrast, application of the rule that if both parties attach the same meaning to an expression, that meaning prevails, depends on a determination of the parties' mental states. I call the doctrines that lie at each end of this spectrum $o b$ jective and subjective.

A second spectrum runs from the pole of standardization to the pole of individualization. A contract law doctrine lies at the standardized pole if its application depends on an abstract variable that is unrelated to the intentions of the parties or the particular circumstances of the transaction. A contract law doctrine lies at the individualized pole if its application depends on situation-specific variables that relate to intentions and circumstances. For example, application of the doctrine that adequacy of consideration will not be reviewed depends on a single variable, the presence of a bargain, that is deliberately designed to screen out all information concerning intentions and circumstances. In contrast, application of the doctrine of unconscionability depends on a number of situation-specific variables that are wholly concerned with that sort of information. I call the principles that lie at each end of this spectrum standardized and individualized.

A third spectrum runs from the static to the dynamic. A contract law doctrine lies at the static pole if its application turns entirely on what occurred at the moment in time when a contract was formed. A contract law doctrine lies at the dynamic pole if its application turns in significant part 
on a moving stream of events that precedes, follows, or constitutes the formation of a contract. For example, the plain-meaming rule is not only objective but static, because it limits interpretation to what occurred at the moment in time when a written contract was executed. In contrast, a rule that allows background circumstances and negotiations to be taken into account in interpretation is dynamic, because it turns in significant part on the stream of events before the moment of contract-formation.

A fourth spectruin runs from the binary to the multi-faceted. Contract law doctrines are binary if they organize the experience within their scope into only two categories. Contract law doctrines are multi-faceted if they organize the experience within their scope into several categories, including one or more intermediate categories. For example, Williston famously argued that when it came to damages, the only choice in contract law was the binary choice between no damages and expectation damages. ${ }^{2}$ In contrast, modern contract law provides a multi-faceted menu of no damages, expectation damages, reliance damages, and restitutionary damages.

In the late mineteenth and early twentieth centuries, the school of thought now referred to as classical contract law, which found its central inspiration in Langdell, Holmes, and Williston, and its central expression in the Restatement (First) of Contracts ("Restatement First"), held virtually absolute sway over contract theory. Classical contract law was a rigid, rather than a supple, instrument, which purported to employ axiomatic and deductive rather than substantive reasoning. Its rules were often responsive to neither the actual objectives of the parties, the actual facts and circumstances of the parties' transaction, nor the dynamic character of contracts. Instead, the rules of classical contract law were centered on a single abstraction, the reasonable person; on a single kind of promise, the bargain promise; and on a single moment in time, the moment of contractformation.

Accordingly, classical contract law doctrines lay almost wholly at the objective, standardized, and static poles, and also tended to be binary. In contrast, modern contract law employs substantive rather than formal reasoning, and pervasively (although not completely) consists of principles that are individualized, dynamic, multi-faceted, and, in appropriate cases, subjective.

The organization of this Essay is as follows: Part I considers the shift in the nature of contract law reasoning from formal to substantive. Part II considers the shift from a body of contract law that was rigorously standardized and objective to a body of contract law that is, where appropriate, individualized and even subjective. Because I have addressed the issues discussed in Parts I and II at length elsewhere, the treatunent of those issues in this Essay will be relatively brief. My primary emphasis in this Essay

2. 4 A.L.I. Proc. 88-89, 91-92, 95-96, 98-99 (1926). 
will be to consider the shift from static to dynamic rules and, in passing, from binary to multi-faceted rules. These issues will be discussed in Part III.

\section{I}

\section{The Nature of Contract-Law Reasoning}

Reasoning in common law areas like contracts may be formal or substantive. I will call propositions of legal doctrine doctrinal propositions, and nondoctrinal propositions-in particular, propositions of morality, policy, and experience-social propositions. ${ }^{3}$ The premise of formal legal reasoning is that law consists of doctrinal propositions that are autonomous from social propositions. In contrast, the premise of substantive legal reasoning is that doctrinal propositions are not autononous from social propositions.

Formal legal reasoning may be axiomatic, deductive, or both. Axiomatic legal reasoning takes as a premise that fundamental doctrines can be established on the ground that they are self-evident. ${ }^{4}$ In the strictest versions of axiomatic theories, such as classical contract law, no room is allowed for justifying doctrinal propositions on the basis of moral and policy propositions. So, for example, Langdell, speaking to the question whether an acceptance by mail was effective on dispatch, said

The acceptance ... must be communicated to the original offeror, and until such communication the contract is not made. It has been claimed that the purposes of substantial justice, and the interests of contracting parties as understood by theniselves, will be best served by holding that the contract is coniplete the monient the letter of acceptance is mailed; and cases have been put to show that the contrary view would produce not only unjust but absurd results. The true answer to this argunient is that it is irrelevant. ${ }^{5}$

Deductive legal reasoning is based on the idea that many or most doctrines can be established solely by deduction from other, more fundamentaI doctrines that are taken as the major premises of syllogisms. As Oliver Wendell Holmes observed, axiomatic theories may easily be coupled with deductive theories: "I sometimes tell students that the law schools pursue an inspirational combined with a logical nethod, that is, the

3. See Melvin A. Eisenberg, The Nature OF the Common Law 14-42 (1988).

4. In some cases, the axiom is purportedly derived at least in part from precedents, but even in such cases it is usually clear that precedents do not really control the matter, because they could be lined up to support a variety of conflicting doctrinal propositions. For example, at the time the bargain theory of consideration became enshrined in the classical canon the precedents had held various kinds of nonbargain promises enforceable.

5. C. C. LanGdell, Summary OF the Law of ConTracts $15,20-21$ (2d ed. 1880). 
postulates are taken for granted upon authority without inquiry into their worth, and then logic is used as the only tool to develop the results."

Classical contract law was based on just such a coupling. It conceived contract law as a small set of core doctrines-axioms-that were justified on the ground that they were self-evident, and as a larger set of doctrines that were justified largely on the ground that they could be deduced from the axioms. For example, it was an axiom of classical contract law that only bargain promises had consideration (that is, were enforceable), although exceptions were recognized for certain kinds of promises (such as those under seal) that were enforceable on strictly precedential rather than principled grounds. The issue then arose whether a firm offer-an unbargained-for promise to hold an offer open-was enforceable. The conclusion of classical contract law was that it was not. ${ }^{7}$ This conclusion was justified by deduction alone. The major premise was that only bargains had consideration. The minor premise was that a promise to hold a firm offer open is not bargained-for. The conclusion was that a firm offer is unenforceable.

Another axiom of classical contract law was that bargains were formed by offer and acceptance. The issue then arose whether an offer for a unilateral contract-an offer to be accepted by the performance of an act-was revocable before performance had been completed even if the offeree had begun to perform. The conclusion of classical contract law was that the offer was revocable. ${ }^{8}$ This conclusion too was justified by deduction alone. The major premise was that an offeror could revoke an offer at any time prior to acceptance, unless he had made a bargamed-for promise to hold the offer open. The minor premise was that an offer for a unilateral contract was not bargained for and was not accepted until performance of the act had occurred. The conclusion was that an offer for a unilateral contract was revocable even after the offeree had begun to perform.

Langdell's view that an acceptance can be effective only on receipt was also based on deductive reasoning: By axiom, a bargain could be formed only by offer and acceptance. By axiom, an expression could not be an acceptance unless it was communicated to the addressee. By deduction, an acceptance could be effective only on receipt.9

6. Oliver Wendell Holmes, Law in Science and Science in Law, in Collected Legal PAPERS 210, 238 (1920).

7. See, e.g., Dickinson v. Dodds, 2 Ch. D. 463, 465 (1876).

8. See, e.g., Petterson v. Pattberg, 161 N.E. 428,430 (N.Y. 1928).

9. Of course, even during the classical period most jurisdictions adopted the mailbox rule, under which a communication is effective on dispatch. However, the English courts, at least, justificd this rule on the specious deductive ground that the post office was an agent of the offeror, so that depositing a letter with the post office constituted a communication to the offeror through his agent. See Household Fire \& Carriage Accident Ins. Co. v. Grant, 4 Ex. D. 216, 219 (1879). 
Formal legal reasoning is not defensible. To begin with, axiomatic theories of law cannot be sustained. No significant doctrinal proposition can be justified on the ground that it is self-evident. Rather, doctrinal propositions can be ultimately justified only by propositions of morality, policy, and experience. I will call doctrines that are justified on this basis normatively justified doctrines.

A distinction must be drawn here between the justification of a doctrine and the justification for following a doctrine. Once a doctrine has been adopted, in the short run following the doctrine may be justified by such elements as protection of reliance, the desirability of stability in the law, and the possibility of unintended consequences when changes are made. However, these elements only justify following the doctrine, not the doctrine itself, and in any event only infrequently result in the long continuation of doctrines that are not normatively justified.

Deductive theories are no more sustainable than axiomatic theories. A doctrine, even if normatively justified, may serve only as a prima facie premise for legal reasoning, and cannot serve as a conclusive premise of legal reasoning, because all doctrines are always subject to as-yetunarticulated exceptions based on social propositions. Such an exception may be made because the social propositions that support the doctrine do not extend to a new fact pattern that is within the doctrine's scope. Alternatively, such an exception may be made because a new fact pattern that is within the doctrine's stated scope brings into play other social propositions that require the formulation of a special rule for the fact pattern.

For example, suppose there is a normatively justified doctrine that bargain promises-promises made as part of a bargain-are enforceable. A case now arises, for the first time, in which a party to a bargain with a minor seeks to enforce the contract against the minor. If the applicability of a doctrinal rule to a new fact pattern that is within the stated scope of the rule could be justified by deductive logic alone, the minor would be liable. The major premise would be that bargains are enforceable. The minor premise would be that the minor made a bargain. The conclusion would be that the minor is liable. But this conclusion should not be drawn, because the social propositions that support the bargain rule do not support the application of the rule to bargains with minors. One reason for the doctrinal rule that bargain promises are enforceable is that actors are normally good judges of their own interests. This reason for the rule does not extend to minors. Therefore, the rule should be made subject to an exception for minors.

Similarly, suppose there is a normatively justified doctrine that donative promises-promises to make gifts-are unenforceable. A case now arises in which a donative promise was reasonably relied upon to the promisee's cost. If the apphicability of a doctrinal rule to a new fact pattern that is within the stated scope of the rule could be justified by deductive 
logic alone, the promissor would not be liable. The major premise would be that donative promises are unenforceable. The minor premise would be that the promise was donative. The conclusion would be that the promise is unenforceable. But this conclusion should not be drawn, because a social proposition other than those that support the donative promise principle applies to the case: when one person, $A$, addresses an expression to another, $B$, which communicates that $A$ is committed to take a certain course of action, and $A$ knows or should know that $B$ will incur costs if $A$ does not take the action, $A$ should take steps to ensure that if he does not take the action, $B$ will not suffer a loss. ${ }^{10}$ This proposition is weightier, in the donative promise context, than the propositions that support the donative promise rule in the absence of reliance. Therefore, an exception should be made to the donative promise rule when the promisee has reasonably relied upon the promise.

In short, the applicability of a doctrine to a fact pattern that is within the stated scope of the doctrine is always dependent on a conclusion that social propositions do not justify creating an exception for the fact pattern. Correspondingly, an application of a doctrine that seems perfectly straightforward and easy is not so as a matter of deductive logic alone, but because social propositions do not justify the creation of an exception to cover the case at hand.

In contrast to the formal reasoning of classical contract law, modern contract law reasoning is substantive. That is, modern contract law seeks to justify doctrines on the basis of social propositions. Of course, doctrines have a role to play in substantive legal reasoning, but that is because of the social values that underlie doctrinal stability, not because doctrines are either self-evident or established by deduction. In general, the algorithm that describes modern contract law reasoning is this: If a rule stated in applicable precedents is substantially congruent with what the court believes would be the best rule under applicable social propositions, the stated rule normally should and will be followed even though it falls somewhat short of the best rule. However, if the stated rule lacks substantial social congruence, the courts normally should and will either create exceptions to the stated rule-if need be, exceptions that are inconsistent with the stated rule-or will overrule the stated rule. ${ }^{11}$ Accordingly, in modern times many of the most firmly rooted doctrines of classical contract law have been either radically transformed or wholly uprooted because the courts have come to perceive the doctrines as not normatively justified. This is true, for example, of the rule that only bargain promises are enforceable, and the rule that an offer for a unilateral contract is revocable before performance

10. See Thomas Scanlon, Promises and Practices, 19 PHIL. \& PUB. AFF. 199, 202-03 (1990).

11. See EISENBERG, supra note 3, at 104-40. 
has been completed even if the offeree had begun to perform. Other examples will be discussed in the balance of this Essay.

II

\section{The Emergence of Individualized ANd Subjective Principles of Contract LAW}

Under the basic contracts principle, contract law should effectuate the objectives of parties to a promissory transaction if appropriate conditions are satisfied and subject to appropriate constraints. Given this focus on the objectives of the parties to a promissory transaction, the rules of contract law should often be formulated so that their application will turn on the individual circumstances of a transaction and, in certain cases, on the parties' subjective intentions. Accordingly, the overriding preference of classical contract law for objective and standardized rules was inappropriate. Instead, whether any given rule of contract law should be standardized or individualized, or objective or subjective, must be decided on a rule-byrule basis. In this Part, I review developments in the area of consideration, interpretation, and remedies to exemplify the way in which modern contract law has noved away from the rigorously objective and standardized character of classical contract law rules to a regime of rules that are often individualized and sometimes subjective. ${ }^{12}$

\section{A. Consideration}

The law of consideration presents the first great issue of contract law: what kinds of promises should the law enforce? It seems relatively clear that not every kind of promise should be enforced and that there may be various reasons for enforcing different kinds of promises. A basic axiom of the classical school, however, was that to constitute consideration a promise or performance unust be bargained-for-the so-called bargain theory of consideration. Accordingly, the classical school rejected the enforceability of nonbargain promises as a matter of principle (although several very narrow categories of nonbargain promises, such as promises under seal, were deened enforceable on strictly precedential grounds). For example, under classical contract law a donative promise was unenforceable even if relied upon, and so too was a promise based on a past benefit that gave rise to a moral obhigation to make compensation.

Ironically, as the bargain theory of consideration was actually elaborated by the classical school, it could be satisfied even though no bargain had been inade. Under the doctrine of nominal consideration, embraced by Holmes and Restatement First, the bargain form alone would suffice to

12. The analysis in this Part draws on my Article, The Responsive Model of Contract Law, 36 Stan. L. Rev. 1107 (1984). 
make a promise enforceable. Holmes expressed his view in two wellknown aphorisms: "consideration is as much a form as a seal," 13 and

it is the essence of a consideration, that, by the terms of the agreement, it is given and accepted as the motive or inducement of the promise. Conversely, the promise must be made and accepted as the conventional motive or inducement for furnishing the consideration. The root of the whole matter is the relation of reciprocal conventional inducement, each for the other, between consideration and promise. ${ }^{14}$

By the term "reciprocal inducement," Holmes meant bargain. By the term "conventional," Holmes apparently meant a formal expression whose meaning and significance is artificially determined, like a bidding convention in the game of bridge. Therefore, if the parties deliberately adopted the convention (forn) of a bargain, the law would enforce their promises as though they had deliberately adopted the convention (form) of the seal. An illustration in Restatement First expressed the same idea:

A wishes to make a binding promise to his son $\mathrm{B}$ to convey to $\mathrm{B}$ Blackacre, which is worth $\$ 5000$. Being advised that a gratuitous promise is not binding, A writes to $B$ an offer to sell Blackacre for $\$ 1$. B accepts. B's promise to pay $\$ 1$ is sufficient consideration. ${ }^{15}$

Only by coupling the bargain theory of consideration with the doctrine of nominal consideration could the classical school provide an account of consideration that satisfied the school's overriding preference for standardization and rigorous objectivity, because taken alone the bargain theory failed to satisfy the classical school's overriding preference for objective and standardized rules. A bargain is an exchange in which each party views the performance that he undertakes as the price of the performance undertaken by the other. Whether each party to an exchange views his performance as the price of the other's - that is, whether an exchange is a bargain-ultimately depends on the parties' subjective intent. Similarly, only subjective intent separates transactions that are bargains in substance from transactions that are bargains merely in form. By coupling the bargam theory of consideration with the doctrine of nominal consideration, an

13. Krell v. Codman, 28 N.E. 578, 578 (Mass. 1891).

14. Oliver Wendell Holmes, The Common Law 293-94 (Boston, Little, Brown \& Co. 1881); see also Wisconsin \& Mich. Ry. v. Powers, 191 U.S. 379, 386 (1903) (Holmes, J.) (holding that using the form of consideration indicates that the parties intended to be bound).

15. Restatement (FiRst) of Contracts \$ 84 illus. 1 (1932) [hereinafter Restatement First]. Even in the era of classical contract law, the case law frequently diverged, at least in part, from the classical canon. For example, the case law generally rejected the doctrine of nominal consideration, except in the option and surety contexts, where the setting is commercial and reliance is likely. Professor Braucher, when working on Restatement First, remarked that "I reviewed the criticism [of illustration 1 to $\$ 84$ of Restatement First] and tried to find authority on the subject, and the fact is that I was unable to find any authority whatever to support this illustration. I was able to find quite a lot of authority exactly contrary to the illustration ..." 42 A.L.I. Proc. 251 (1965). 
objective and abstract variable-the presence or absence of the bargain form-would control the issue of enforceability, and enforceable promises would be separated from unenforceable promises by a token that doubled as a bright line.

During the last fifty years, the law of consideration properly has moved from the standardization and objectivity of the bargain theory of consideration to a rich menu of individualized principles that reflect both objective and subjective elements. For example, the standardized principle that a donative promise is not enforceable even if it is relied upon ${ }^{16}$ has been replaced by the individualized principle that action in reliance makes a promise enforceable if the promisor should reasonably expect that the promise would induce the action (an individualized test) and the promise does induce the action (a subjective test). ${ }^{17}$ The rigorously objective principle that forbearance to assert a claim is consideration only if the claim is reasonable ${ }^{18}$ has been replaced by the partly subjective principle that forbearance to assert a claim is consideration if the claim is either doubtful in fact or honestly held. ${ }^{19}$ The standardized principle that past consideration does not make a promise enforceable ${ }^{20}$ is being replaced by the individualized principle that a promise to make compensation for a past benefit that gave rise to a moral obligation is enforceable. ${ }^{21}$ Perhaps most striking, the Restatement (Second) of Contracts ("Restatement Second") has reversed the position of Restatement First on nominal consideration, and adopted a test that requires a bargain in fact rather than in form. ${ }^{22}$

\section{B. Interpretation}

Classical contract law adopted a theory of interpretation that was purely, or almost purely, objective. As stated in Woburn National Bank $v$. Woods:.23

A contract involves what is called a meeting of the minds of the parties. But this does not mean that they must have arrived at a common mental state touching the matter in hand. The standard by which their conduct is judged and their rights are limited is not internal, but external. In the absence of fraud or incapacity, the question is: What did the party say and do? "The making of a

16. See, e.g., Kirksey v. Kirksey, 8 Ala. 131, 133 (1845).

17. See, e.g., Restatement (Second) OF Contracts $\& 90$ (1979) [hereinafter Restatement SECOND].

18. See, e.g., Springstead v. Nees, 109 N.Y.S. 148, 150 (App. Div. 1908).

19. See, e.g., ReSTATEMENT SeCond, supra note $17, \S 74(1)$.

20. See, e.g., Harrington v. Taylor, 36 S.E.2d 227, 227 (N.C. 1945).

21. See Restatement Second, supra note 17, § 86; Melvin A. Eisenberg, The Principles of Consideration, 67 CORN. L. REv. 640, 663-64 (1982).

22. See Restatement SeCond, supra note $17, \S 71, \mathrm{cmt}$. b, illus. $4-5$. The Restatement now gives special treatment to nominal consideration in option and surety contexts. See Id. $\$ \S 87-88$.

23. 89 A. 491, 492 (N.H. 1914). 
contract does not depend upon the state of the parties' minds; it depends upon their overt acts." 24

Classical contract law carried objectivism so far that it overrode the actual shared intentions of the parties. Thus, Williston:

It is even conceivable that a contract shall be formed which is in accordance with the intention of neither party. If a written contract is entered into, the meaning and effect of the contract depends on the construction given the written language by the court, and the court will give that language its natural and appropriate meaning; and, if it is unambiguous, will not even admit evidence of what the parties may have thought the meaning to be. ${ }^{25}$

And Learned Hand:

A contract has, strictly speaking, nothing to do with the personal, or individual, intent of the parties. A contract is an obligation attached by the inere force of law to certain acts of the parties, usually words, which ordinarily accompany and represent a known intent. If, however, it were proved by twenty bishops that either party, when he used the words, intended something else than the usual meaming which the law imposes upon them, he would still be held, unless there were some mutual mistake, or something eIse of the sort. ... [W] [Watever was the understanding in fact of the banks [in this case] ... of the legal effect of this practice between them, it is of not the slightest consequence, unless it took form in some acts or words, which, being reasonabIy interpreted, would have such meaning to ordinary inen. ${ }^{26}$

If, however, as under the basic contracts principle, contract law is viewed as a functional instrument whose purpose is to effectuate the objectives of parties to a promissory transaction if appropriate conditions are

24. Id. at 492 (quoting HolmES, supra note 14 , at 307 ).

25. 1 Samuel Williston, a Treatise on the LaW of Contracts $\$ 95$ (1st ed. 1920).

26. Hotchkiss v. National City Bank, 200 F. 287, 293-94 (S.D.N.Y. 1911), aff'd, 201 F. 664 (2d

Cir. 1912), aff'd, 231 U.S. 50 (1913); Restatement First also illustrates this point:

$A$ and $B$ are engaged in buying and selling shares of stock from one another and agree orally for the purpose of concealing the nature of their dealings that in transactions between them the word "buy" shall be used to mean "sell," and that the word "sell" shall be uscd to mean "buy." A sends a written offer to B to "sell" certain shares of stock. B, having in mind the oral agreement, accepts the offer and tenders the shares to A. On A's refusal to accept the tender, B brings an action against him. B cannot recover, unless reformation is had of the writings. The private oral agreement cannot make "buy" mean "sell," though a private agreement may give to a word which has no inconsistent meaning, a meaning in accordance with the agreement.

RESTATEMENT FIRST, supra note $15, \$ 231$, illus. 2. Holmes was in accord:

I do not suppose that you could prove, for purposes of construction as distinguished from avoidance, an oral declaration or even an agreement that words in a dispositive instrument making sense as they stand should have a different meaning from the common one; for instance, that the parties to a contract orally agreed that when they wrote five hundred feet it should mean one hundred inches, or that Bunker Hill Monument should signify Old South Church.

Oliver Wendell Holmes, The Theory of Legal Interpretation, 12 HARV. L. REV. 417, 420 (1899). 
satisfied and subject to appropriate constraints, then the principles of interpretation should be responsive, where appropriate, to subjective intentions. Accordingly, under modern contract law subjective elements have an important place in interpretation. This point is well illustrated by four central principles of interpretation in modern contract law:

Principle I: If the parties subjectively attach different meanings to an expression, neither party knows that the other attaches a different meaning, and the two meanings are not equally reasonable, the more reasonable meaning prevails. This Principle is adopted in Restatement Second section 201(2)(b):

Where the parties have attached different meanings to a promise or agreement or a term thereof, it is interpreted in accordance with the meaning attached by one of them if at the time the agreement was made

....

(b) that party had no reason to know of any different meaning attached by the other, and the other had reason to know the meaning attached by the first party. ${ }^{27}$

Principle I is based in significant part on the concept of liability for fault. $A$ is at fault -is negligent-if he uses an expression that he should realize would lead a reasonable person in $B$ 's position to understand that $A$ attaches a given meaning, $M$, to the expression, when in fact $A$ attaches meaning $N$. If $B$ attaches meaning $M$, and thereby suffers wasted reliance, or the defeat of a legitimate expectation, when $A$ insists on meaning $N, A$ should compensate $B$. Although Principle I is primarily objective, it has a subjective element as well. The more reasonable meaning will prevail only if one of the parties has actually (subjectively) attached that meaning to the expression.

Principle II: If the parties subjectively attach different meanings to an expression, neither party knows that the other attaches a different meaning, and the two meanings are equally reasonable, neither meaning prevails. This Principle is adopted in the Restatement Second section 20(1):

There is no manifestation of mutual assent to an exchange if the parties attach materially different meanings to their manifestations and

(a) neither party knows or has reason to know the meaning attached by the other; or

(b) each party knows or each party has reason to know the meaning attached by the other. ${ }^{28}$

27. RESTATEMENT SECOND, supra note $17, \S 201(2)$.

28. Id. $\S 20(1)$. 
Principle II is consistent with Principle I. If parties to a promissory transaction subjectively attach different meanings to their expressions, and in attaching these different nieanings both parties are either equally faultfree or equally at fault, there is no reason why one meaning rather than the other should prevail.

Principle II is associated with Raffles $v$. Wichelhaus, ${ }^{29}$ the Peerless case. Seller agreed to sell to Buyer 125 bales of Surat cotton to arrive at Liverpool "ex [ship] 'Peerless' from Bombay." 30 There were, however, two ships named Peerless that sailed from Bombay. One sailed in October, and one in December. Seller neant the December Peerless, and shipped Surat cotton on that ship. Buyer meant the October Peerless, and refused to accept the cotton shipped on the December Peerless. ${ }^{31}$ Seller sued for breach of contract. The court held for Buyer on the ground that there was no "consensus ad idem," 32 so that no contract was formed. To preserve the classical school program, Holmes argued that the result in Peerless could be explained by objective theory. "The true ground of the decision was not that each party meant a different thing from the other ... but that each said a different thing. The plaintiff offered one thing, the defendant expressed his assent to another. ${ }^{\text {"33 }}$ But if both parties subjectively meant the December Peerless, Buyer should have been deemed in breach; and Seller should have been deemed in breach if both parties subjectively meant the October Peerless. Holmes had it backwards: the result in Peerless is correct because they meant different things, not because they said different things.

Principle III: If the parties subjectively attach the same meaning to an expression, that meaning prevails even though it is unreasonable. Principle III squarely reverses the strict objectivism of classical contract law under which the subjective intention of the parties was irrelevant even if mutual. Again, the objectivists had it wrong. Where both parties attach the saine, unreasonable, meaning to an expression, one or both parties nuay have been at fault in their use of language, but the fault caused no injury. Indeed, a party who presses an interpretation that he himself did not hold is himself at fault.

Principle III is adopted in Restatement Second section 201(1). That section provides that "[w] $\mathrm{w}$.re the parties have attached the saine meaning to a promise or agreenient or a term thereof, it is interpreted in accordance with that meaning." ${ }^{34}$ Under section 201(1), reasonableness becomes

\footnotetext{
29. 159 Eng. Rep. 375 (Ex. 1864).

30. Id. at 375 .

31. The facts are as stated in Buyer's answer, to which Seller demurred. See id.

32. Id. at 376.

33. HOLMES, supra note 14 , at 309.

34. RESTATEMENT SECOND, supra note 17 , $\$ 201(1)$. Similarly, Restatement Second $\S 20$ provides:
} 
relevant only where there is not a mutually held subjective interpretation. Thus, Restatement Second stands the classical school's position on its head, by giving primacy to mutually held subjective interpretation, and resorting to an objective or reasonable meaning only in the absence of a mutually held subjective meaning.

Principle IV: If the parties, $\mathrm{A}$ and $\mathrm{B}$, attach different meanings, $\mathrm{M}$ and $\mathrm{N}$, to an expression, and $\mathrm{A}$ knows that $\mathrm{B}$ attaches meaning $\mathrm{N}$ while $\mathrm{B}$ does not know that $\mathrm{A}$ attaches meaning $\mathrm{M}$, meaning $\mathrm{N}$ prevails even if it is less reasonable than meaning $\mathrm{M}$. This Principle is adopted in Restatement Second section 201(2):

Where the parties have attached different meanings to a promise or agreement or a term thereof, it is interpreted in accordance with the meaning attached by one of them if at the time the agreement was made

(a) that party did not know of any different meaning attached by the other, and the other knew the meaning attached by the first party..... ${ }^{35}$

Principle IV is largely subjective. It is supported by a fault analysis. $B$ may have been at fault in attaching meaning $N$ to the expression, but $A$ was more at fault in allowing $B$ to proceed on the basis of an interpretation that $A$ knew $B$ held, at least when $B$ did not know that $A$ held a different interpretation.

\section{Remedies}

In the area of remedies, the preference of classical contract law for standardized rules was reflected in two basic ways: damage formulas were often based on market prices, and specific performance was rarely awarded.

\section{Market-price measures of damages}

In the era of classical contract law, many damages measures were based on market price. ${ }^{36}$ These measures were standardized, because they

(1) There is no manifestation of mutual assent to an exchange if the parties attach materially different meanings to their manifestations and

(a) neither party knows or has reason to know the meaning attached by the other; or other.

(b) each party knows or each party has reason to know the meaning attached by the Id. $\S 20(1)(\mathrm{a})-(\mathrm{b})$.

35. Id. $\S 201(2)$. Similarly, Restatement Second $\S 20$ provides: "The manifestations of the parties are operative in accordance with the meaning attached to them by one of the parties if ... that party does not know of any different meaning attached by the other, and the other knows the meaning attached by the first party." Id. § 20(2)(a).

36. See UNIF. SALES ACT $\S 67$ (withdrawn 1951) (buyer's damages), $\S$ 63-64 (seller's damages); DAN B. DobBs, HANDBOOK ON THE LAW OF REMEdies 870 (1973). 
turned on the run of transactions between buyers and sellers as a class. In contrast, the modern rules of the Uniform Commercial Code (U.C.C.) provide more-individualized damages remedies. For example, upon a breach by the seller the buyer may cover, and measure damages by the difference between the contract price and his actual cover price. ${ }^{37}$ Similarly, upon a breach by the buyer, the seller may resell the goods and measure damages by the difference between the resale price and the contract price. Furthermore, if the market-price measure of damages is inadequate to put a seller in as good a position as performance would have done, then the measure of damages is the profit that the seller would have made from the buyer's performance..$^{38}$ Unlike market-price damages, the cover, resale, and lost-profit measures are individualized. They turn not on the run of transactions between buyers and sellers as a class, but on the specific transaction in which the injured buyer or seller actually engaged.

\section{Specific performance}

The overriding preference of the school of classical contract law for standardized principles was also reflected in its strong disfavor of the highly individualized remedy of specific performance. So, for example, under classical contract law, in contracts for the sale of goods specific performance was available only if the goods were unique..$^{39}$ Essentially, this was a standardizcd test based on the characteristics of the goods, rather than on the individualized objectives and situation of the buyer.

In contrast, modern contract law generally has liberalized the availability of specific performance. For example, U.C.C. section 2-716(1) gives a buyer the right to specific performance "where the goods are unique or in other proper circumstances." 40 The official comment states that Article 2 "seeks to further a more liberal attitude than some courts have shown in connection with the specific performance of contracts of sale." ${ }^{41}$ In addition, U.C.C. section 2-716(3) gives the buyer a right to the comparable remedy of replevin for goods identified to the contract if, after reasonable effort, the buyer is unable to effect cover or the circumstances reasonably indicate that such an effort will be unavailing. ${ }^{42}$ The U.C.C. also provides the seller with a counterpart to the buyer's remedies of specific performance and replevin: under section 2-709(1), the seller can recover the price of goods identified to the contract if, after reasonable effort, he

\footnotetext{
37. See U.C.C. $\$ 2-712$.

38. See U.C.C. $\$ 2-708(2)$.

39. See, e.g., DoBBS, supra note 36 , at 834 .

40. U.C.C. $\$ 2-716(1)$ (emphasis added).

41. U.C.C. $\$ 2-716$ official $\mathrm{cmt}$. 1.

42. See U.C.C. § 2-716(3).
} 
cannot resell them at a reasonable price, or if the circumstances reasonably indicate that he will be unable to do so. ${ }^{43}$

\section{III}

\section{The Emergence of Dynamic Principles of Contract Law}

I turn now to the emergence of dynamic principles of contract law; that is, principles of contract law whose application does not depend solely on what occurred at the moment in time when a contract was formed, but instead turn on the moving stream of events that precedes, follows, or constitutes the formation of a contract. This Part, like this Essay in general, has a normative and a positive thesis.

The positive thesis is that contract law has been marked by a shift from static to dynamic principles. The normative thesis is that this shift is proper. Promissory transactions seldom occur in an instant of time. They have a past, a present, and a future, and often it is not easy to say where the past ends and the present begins (because, for example, concluding a deal is often a gradual process), or where the present ends and the future begins (because, for example, the contract is partly what it was when originally nade and partly what it becomes thereafter). Since promissory transactions seldoin occur in an instant of time, contract law should reflect the reality of contracting by adopting dynamic principles that parallel that reality, rather than static principles that deny it. In this Part, I deinonstrate how contract law has, appropriately, noved froin static to dynamic principles in four critical areas: consideration, remedies, offer and acceptance, and interpretation.

\section{A. Consideration}

As shown in Part II, the axiom of classical contract law that as a matter of principle only bargains had consideration-were enforceable-was an objective and standardized rule, particularly when coupled with the rule that the use of the bargain form sufficed. In contrast, the modern rules that a promise is enforceable where a party has relied on it, or where the promise is to pay for a past benefit that gives rise to a moral obligation to nnake compensation, are examples of individualized rules, because they depend on the facts and circumstances of each case.

The modern rules concerning the enforceability of such promises are dynamic as well as individualized. The application of the bargain principle turns on a single moment in time. In contrast, the reliance principle ties a promise to a course of action that occurs after the promise is made. The

43. Under U.C.C. $\$ 2-501(1)$, goods are "identified to the contract" (a) at the time the contract is made, if the contract is for the sale of goods already existing and identified, and (b) at the time the goods are shipped, marked, or otherwise designated as goods to which the contract refers, if the contract is for the sale of future goods. See U.C.C. $\$ 2-501(1)(a)-(b)$. 
modern rule that a promise to pay for a past benefit that gave rise to a moral obligation to make compensation is enforceable is also a dynamic rule, because its application depends on the past benefit as well as the present promise. The same is true of the modern law of unilateral contracts: under classical contract law, an offer for a umilateral contract was unenforceable unless and until performance had been completed. At the moment of completion, a contract was formed. Until then, the offer was revocable on the ground that it lacked consideration. In contrast, the modern law of unilateral contracts adopts the dynamic rule that once the offeree begims performance he has the right to accept the offer by completing performance, provided that he begins, continues, and completes performance in a reasonable time. ${ }^{44}$

The most striking movement from static to dynamic rules in the area of consideration involves bargains themselves. A central rule of classical contract law is the legal-duty rule, that a promise to perform a legal duty is not consideration. Under this rule, an agreement to make a one-way readjustment of a contract, that is, a readjustment under which only one party's rights are changed, is unenforceable. I will refer to such one-way readjustments as modifications. ${ }^{45}$

Modifications normally fall imto one of two patterns. In one pattern, $A$ is contractually obliged to render some performance to $B$ in exchange for a price, $\$ X$. The parties then agree that $B$ will pay more than $\$ X$ for $A$ 's performance, by adding an increment, $\$ M$. After $A$ performs, $B$ pays $\$ X$ rather than $\$ X+\$ M$. Under the legal-duty rule, $B$ is not liable for the increment that he agreed to pay.

In the second pattern, $A$ owes $\$ X$ to $B$, and the parties agree that $B$ will accept $\$ L$, which is less than $\$ X$, in full satisfaction of $A$ 's debt. After $A$ pays $\$ L$ to $B, B$ sues for $\$ X-L$, the difference between what $A$ paid and what he originally owed. Under the legal-duty rule, $A$ is liable for that difference.

For the most part, the two patterns raise the same issues. For ease of exposition, I discuss only cases that fall within the first pattern.

In the view of classical contract law, the legal-duty rule needed no moral or policy justification, because it was a self-evident axiom. Sir Frederick Pollock, for example, said that "[i]t seems obvious that an express promise by $A$ to $B$ to do something which $B$ can already call on him to do can in contemplation of law produce no fresh advantage to $B$ or detriment to $A$, and therefore will not be a good consideration. ${ }^{246}$ In fact,

44. See Restatement SeCond, supra note $17, \$ 45$.

45. The analysis here draws on my Article, Probability and Chance in Contract Law, 45 UCLA L. REv. 1005, 1034-41 (1998).

46. Sir Frederick Pollock, Principles of Contract: A Treatise on the General Principles Concerning the Validity of Agreements in the LaW of England 181 (10th ed. 1936). 
however, the legal-duty rule cannot be rationalized on axiomatic grounds. No rule can be rationalized on such grounds, least of all the legal-duty rule, which violates the more basic bargain principle whenever the modification is itself a bargain, as is often the case.

In modern times, therefore, attempts have been made to justify the legal-duty rule on normative grounds. The conventional justification (advanced, for example, in Restatement Second) is based on the premise that modifications are commonly made under duress. ${ }^{47}$ But that premise alone, even if true, is not sufficient to justify the legal-duty rule. Because duress is always a defense to a contract, a modification that is made under duress would be unenforceable even in the absence of the legal-duty rule. Accordingly, the duress justification must rest on one of two additional predicates-either that: (i) The proportion of modifications made under duress is so high that it would be a waste of judicial resources to determine whether a particular modification was not made under duress; or (ii) Duress should be conclusively presumed because it is too difficult for a court to determine whether duress was actually present in any given case. Neither of these predicates would be well founded.

First, whether a modification was made under duress is not especially difficult to determine. Call the party who requests a modification $A$, and call the party who grants the modification $B$. The relevant issues are whether $A$ had a good-faith reason for requesting the modification, and whether $B$ lacked practicable freedom to resist $A$ 's request. Courts can easily deal with these issues directly. Indeed, they frequently do so, both under the legal-duty rule ${ }^{48}$ and in cases in which a party invokes the doctrine of economic duress to recover all or part of a payment he has already made. $^{49}$

Second, there is nothing to show that an extremely high proportion of modifications are made under duress, or even that modifications are commonly made under duress. In fact, the opposite is more likely to be true. To begin with, most modifications do not seem to arise out of a desire by $A$ to grab more of the contract surplus because a shift in bargaining power has allowed him to do so. Instead, most modifications seem to arise because at the time the modification is made, the world looks significantly different than it was expected to look at the time the contract was made, either because one or both parties were under a misapprehension when the contract was made, or because events unfolded in a different way than the parties expected.

In an elegant article, Aivazian, Trebilock, and Penny argue that a regime under which modifications are enforceable would be based on static

\footnotetext{
47. See Restatement SECOND, supra note $17, \$ 73 \mathrm{cmt}$. a.

48. See, e.g., Angel v. Murray, 322 A.2d 630 (R.I. 1974).

49. See, e.g., Austin Instrument, Inc. v. Loral Corp., 272 N.E.2d 533 (N.Y. 1971).
} 
considerations, while the legal-duty rule (or more precisely, a rule under which modifications are presumptively unenforceable) reflects dynamic considerations:

The nature of the apparent analytical paradox presented by contract modifications can be stated briefly .... If [most modification situations occur in a context in which one party seeks to exploit bargaining power he has obtained during the course of the relationship] ... then it might be argued that the law should attempt to discourage extortionary, coercive, opportunistic or monopolistic behaviour by refusing to enforce most modifications, perhaps by means of a presumption of invalidity.... On the other hand, especially in commercial contexts where most litigated modification cases seem to arise, it might be argued that parties would typically not enter into modifications unless they both felt better off as a result relative to the position that would or might have been obtained without a modification. Hence, the law should respect the parties' assessment of what course of action best advances their joint welfare and enforce modifications, that is, apply a presumption of validity.

... The paradox described above is the product of a tension between two competing sets of efficiency considerations, which in some cases require difficult trade-offs .... Static efficiency considerations will generally require that contract modifications be enforced on the grounds that the immediate contracting parties perceive mutual gains from recontracting that cannot, at the time modification is proposed, be realized as fully by any alternative strategy. On the other hand, dynamic efficiency considerations focus on the long-run incentives for contracting parties at large .... In the modification context, these dynaimic efficiency considerations adopt an ex ante perspective, rather than the ex post perspective implicit in the static efficiency considerations. Adopting the former perspective, rules that impose no constraints on recontracting may increase the over-all costs of contracting by creating incentives for opportunistic behavior in cases where "holdup" possibilities arise during contract performance. . . . Thus, what is in the best interests of two particular contracting parties ex post contract formation when a modification is proposed and what is in the interests ex ante of contracting parties generally in terms of legally ordained incentives and constraints that minimize the over-all costs of contracting may lead to divergent policy perspectives. $^{50}$

In fact, however, the matter is the other way around. It is often the case that $B$ is willing to modify a contract because he believes that, even

50. Varouj A. Aivazian, et al., The Law of Contract Modifications: The Uncertain Quest for a Bench Mark of Enforceability, 22 OsGoode HALL L.J. 173, 174-75 (1984). 
though the relevant misapprehension or changed circumstance does not rise to the level of a legal defense, as a matter of fair dealing a readjustment should be made to reflect the original purpose of the contractual enterprise, or the equities as they now stand in light of the parties' original tacit assumptions. Alternatively, $B$ might accede to $A$ 's request for a modification out of either reciprocity or the hope of reciprocity. Thus modifications that appear to be one-sided if examined in isolation will often be reciprocal when account is taken of the dynamic ebb and flow of the contractual stream in which the modification is located. For example, $B$ may agree to a modification that favors $A$ for the purpose of reciprocating for past modifications, of either the same or other contracts, that favored $B$. Or, $B$ may agree to a modification that favors $A$ because he believes his agreement will increase the probability that $A$ will consent to future modifications in $B$ 's favor when $B$ is in $A$ 's position under either the same or other contracts.

Thus it is the legal duty rule that is based on a static view on contract, while is a regime under which modifications are enforceable is based upon and furthers a dynamic view of contract. The legal duty rule conceives contracts as static transactions whose terms are fully determined at the moment of contract formation. In contrast, an enforceability regime conceives contracts as evolving processes. The legal duty rule conceives modifications as individual events that occur in isolation. In contrast, an enforceability regime recognizes that there is often an ongoing stream of reciprocity between contracting parties, which may be manifested in modifications. The legal duty rule ignores the values of ongoing dynamic cooperation and accommodation between both parties. In contrast, an enforceability regime takes account of those values. Accordingly, the legal duty rule inhibits both the dynamic evolution of contracts and dynamic reciprocity between contracting parties, while an enforceability regime encourages both the dynamic evolution of contracts as circumstances unfold, and dynamic reciprocity between contracting parties. An enforceability regime also makes the contracting process more efficient, because it allows parties to enter into contracts without negotiating every possible contingency on a static, ex ante basis,, knowing that if misapprehensions or changed circumstances do occur, they can be dealt with by dynamic modifications, ex post.

Modern contract law has been moving away from the static legal duty rule and toward the dynamic enforceability regime. Although the legal-duty rule still has some bite, even courts that believe themselves obliged to follow the rule characterize it as "technical," regard it with "disfavor," 51 and find it to be supported by "neither rhyme nor

51. Chicago, Milwaukee, \& St. Paul Ry. Co. v. Clark, 178 U.S. 353, 365 (1900). 
reason." ${ }^{152}$ The rule has been riddled with inconsistent exceptions, ${ }^{53}$ repudiated by judicial decisions in several states, ${ }^{54}$ and repudiated as to written modifications by statutes in several major jurisdictions..$^{55}$ More generally, the U.C.C. explicitly provides that modifications of contracts for the sale of goods are enforceable, provided they are made in good faith. ${ }^{56}$ More generally still, Restatement Second section 89 provides that a modification of a contract that has not been fully performed on either side is binding "if the modification is fair and equitable in view of circuinstances not anticipated by the parties when the contract was inade." ${ }^{57}$ This principle carves away most of the remaining carcass of the legal duty rule.

\section{B. Interpretation}

In the area of interpretation, the development of dynamic principles in modern contract law fall into two broad categories: the increasing use of the parties' conduct before, and after, the time of contract formation.

\section{Conduct before the time of contract formation}

The proper interpretation of all purposive expressions, including contractual expressions, is necessarily dynamic, because the meaning of a purposive expression is always determined in part by its context, and the context is prior to the expression. Classical contract law did not totally exclude the consideration of prior events in issues of interpretation, but tended to severely limit that consideration under the plain-meaning and parol evidence rules. Under the plain-ineaning rule, where a contract, or, at least, a written contract, has a plain meaning, no evidence from outside the contract is allowed to explain the contract or, indeed, to show that the meaning is not really plain. Accordingly, the plain-meaning rule is a

52. Harper v. Graham, 20 Ohio $105,115,117$ (1851). Other cases criticize the doctrine in similar fashion. See, e.g., Brooks v. White, 43 Mass. (2 Met.) 283, 285-86 (1841); Kellogg v. Richards, 14 Wend. 116 (N.Y. Sup. Ct. 1835); Brown v. Kern, 57 P. 798, 799 (Wash. 1899); Herman v. Schlesinger, 90 N.W. 460, 466 (Wis. 1902).

53. See, e.g., Morrison Flying Serv. v. Deming Nat'1 Bank, 404 F.2d 856, 861 (10th Cir. 1968) (holding that the legal-duty rule is not applicable when there is a preexisting contractual duty owed to a third person); Schwartzreich v. Bauman-Basch, Inc., 131 N.E. 887,890 (N.Y. 1921) (holding that the legal-duty rule is not applicable if the prior contract is mutually rescinded when the new contract is made); Cohen v. Sabin, 307 A.2d 845, 849 (Pa. 1973) (holding that the payment of part of an unliquidated obligation is consideration for the surrender of the balance of the claim even if the amount paid was admittedly due); Angel v. Murray, 322 A.2d 630, 637 (R.I. 1974) (holding that the legal-duty rule is inapplicable if the new contract is fair and equitable in light of circumstances not anticipated when the original contract was made).

54. See, e.g., Dreyfus \& Co. v. Roberts, 87 S.W. 641 (Ark. 1905); Clayton v. Clark, 21 So. 565 (Miss. 1897); Frye v. Hubbell, 68 A. 325 (N.H. 1907).

55. See CAL. CIv. CodE $\$ \S 1524,1541,1697$ (West 1954); Mich. CoMP. LAws ANN. $\S 566.1$ (West 1967); N.Y. GEN. OBLIG. LAW § 5-1103 (McKinney 1964).

56. See U.C.C. \$2-209 and cmt. 1 .

57. RESTATEMENT SECOND, supra note $17, \$ 89$. 
standardized rule, because the only variable on which its application depends is the written text. It is also a static rule, because its applicability depends entirely on an event-the execution of the written text-that occurred at the moment of contract formation.

Similarly, under the classical version of the parol evidence rule, where a written contract appears on its face to be an integration (that is, appears on its face to be complete), a party is not allowed to show the existence of prior agreements relating to the same subject-matter, unless the prior agreements were made for separate consideration or were such as might naturally be made as a separate agreement by parties situated like the parties to the writing. This rule also was standardized and static. It was standardized, because its application turned on what abstract reasonable parties would have intended, not on what the actual parties actually intended. It was static, because its application, like that of the plain-meaning rule (with which it often is confused), depended entirely on events at the moment of contract formation. Because both rules were subject to various exceptions, neither rule absolutely precluded consideration of events prior to contract formation. Nevertheless, both rules severely limited the number of cases in which such events could be taken into account.

Under modern contract law, the situation has changed. To begin with, the plain-meaning rule has been largely abandoned. For example, Restatement Second section 212(1) provides that " $[t]$ he interpretation of an integrated agreement is directed to the meaning of the terms of the writing or writings in the light of the circumstances ... ." ${ }^{58}$ Comment $b$ to this section explains:

It is sometimes said that extrinsic evidence cannot change the plain meaning of a writing, but meaning can almost never be plain except in a context. Accordingly, the rule stated in Subsection (1) is not limited to cases where it is determined that the language used is ambiguous. Any determination of meaning or ambiguity should only be made in the light of the relevant evidence of the situation and relations of the parties, the subject matter of the transaction, preliminary negotiations and statements made therein, usages of trade, and the course of dealing between the parties. ${ }^{59}$

Comment $\mathrm{b}$ to section 214 sets out the reason why the Restatement Second abandoned the plain-meaning rule:

Words, written or oral, cannot apply themselves to the subject matter. The expressions and general tenor of speech used in negotiations are admissible to show the conditions existing when the writing was made, the application of the words, and the meaming or meanings of the parties. Even though words seem on

58. Id. $\S 212(1)$.

59. Id. $\S 212 \mathrm{cmt} . \mathrm{b}$. 
their face to have only a single possible meaning, other meanings often appear when the circumstances are disclosed. In cases of misunderstanding, there must be inquiry into the meaning attached to the words by each party and into what each knew or had reason to know. ${ }^{60}$

The classic judicial statement concerning the intellectual poverty of the plain-meaning rule is that of Justice Traynor in Pacific Gas \& Electric v. G.W. Thomas Drayage \& Rigging Co..61

When the court interprets a contract on this basis, it determines the meaning of the instrument in accordance with the "extrinsic evidence of the judge's own linguistic education and experience." The exclusion of testimony that might contradict the linguistic background of the judge reflects a judicial belief in the possibility of perfect verbal expression. This belief is a remnant of a primitive faith in the inherent potency and inherent meaning of words.

A rule that would limit the determination of the meaning of a written instrument to its four-corners merely because it seems to the court to be clear and unambiguous, would either deny the relevance of the intention of the parties or presuppose a degree of verbal precision and stability our language has not attained.

If words had absolute and constant referents, it might be possible to discover contractual intention in the words themselves and in the nranner in which they were arranged. Words, however, do not have absolute and constant referents. "A word is a symbol of thought but has no arbitrary and fixed meaning like a symbol of algebra or chemistry .... The meaning of particular words or groups of words varies with the verbal context and surrounding circumstances and purposes in view of the linguistic education and experience of their users and their hearers or readers (not excluding judges)

.... A word has no meaning apart from these factors; much less does it have an objective meaning, one true meaning." Accordingly, the meaning of a writing "can only be found by interpretation in the light of all the circumstances that reveal the sense in which the writer used the words." 62

The parol evidence rule, although not abandoned, has been significantly loosened in two relevant respects under modern contract law.

60. Id. $\$ 214 \mathrm{cmt} . \mathrm{b}$.

61. 442 P.2d 641 (Cal. 1968).

62. Id. at 643-45 (citations omitted). 
First, the modern view is that the rule has no application to interpretation, and therefore does not bar evidence of negotiations prior to the moment of contract formation that bears on issues of interpretation. ${ }^{63}$ Second, under modern contract law the issue under the parol evidence rule is not the standardized issue, whether similarly situated abstract reasonable parties would have intended a writing to supersede earlier agreements, but the individualized issue, whether the actual parties had that actual intention. ${ }^{64}$

\section{Conduct after the time of contract formation}

Contract interpretation must not only look at events before contract formation; it must also look at events after that time. Because contracts always evolve, or at least may always evolve, interpretation should take account of the way in which the parties live and grow their contracts. Under U.C.C. section 2-208(1), a court, in interpreting a contract for the sale of goods, is not limited to events at or prior to the time of contract-formation. Instead, "[w]here [a] contract for sale involves repeated occasions by performance by either party with knowledge of the nature of the performance and opportunity for objection to it by the other, any course of performance accepted or acquiesced in without objection shall be relevant to determine the meaning of the agreement." Restatement Second goes a half-step further than the U.C.C. Under Restatement Second, course of performance is not only relevant, but is to be "given great weight in the interpretation of the agreement." 65

In short, modern contract law has appropriately moved from a static conception of interpretation, that tended to focus on the text as of the moment of contract formation, to a dynamic conception, that encompasses events before and after that nıment. To put this differently, under modern contract law the text of a contract runs through time. ${ }^{66}$

63. See, e.g., Garden State Plaza Corp. v. S.S. Kresge Co., 189 A.2d 448, 454 (N.J. 1963):

... [I]nterpretation and construction must necessarily precede protection [under the parol evidence rule] against forbidden contradiction or modification. And in the process of interpretation and construction of the integrated agreement all relevant evidence pointing to meaning is admissible because experience teaches that language is so poor an instrument for communieation or expression of intent that ordinarily all surrounding circumstances and conditions must be examined before there is any trustworthy assurance of derivation of contractual intent, even by reasonable judges of ordinary intelligence, from any given set of words which the parties have committed to paper as their contract.

64. See, e.g., Interform Co. v. Mitchell, 575 F.2d 1270, 1275-77 (9th Cir. 1978).

65. Restatement SeCOND, supra note 17, § 202(4).

66. Conduct subsequent to contract formation was recognized as relevant even before the emergence of modern contract law, but the recognition tended to be grudging. Restatement First section 235(e) provided that "[i]] the conduct of the parties subsequent to a manifestation of intention indicates that all the parties placed a particular interpretation upon it, that meaning is adopted if $a$ reasonable person could attach it to the manifestation." RESTATEMENT FIRST, supra note 15, § 235(e) (emphasis added). Under the rule embodied in this section, subsequent conduct was inadmissible to show a jointly held interpretation unless the interpretation was not only joint but rcasonable. 


\section{Remedies-The Principle of Hadley v. Baxendale ${ }^{67}$}

Contract law draws a sharp distinction between general damages and consequential damages. General damages are the damages that flow from a given type of breach without regard to the injured party's particular circumstances. Consequential damages are damages above and beyond general damages that flow from a breach as a result of the injured party's particular circumstances. Under the principle of Hadley v. Baxendale, consequential damages can be recovered only if, at the time the contract was made, the breaching party had reason to foresee, at some designated level of probability, that the damages in question would be the likely result of breach. This principle reflected the overriding preference of classical contract law for standardized rules, because it tended to substitute the hypothetical damages that would have been incurred by a standardized party for the actual damages incurred by a real party.

Victoria Laundry (Windsor) Ltd. v. Newman Industries Ltd. ${ }^{6}$ illustrates the extent to which standardization was carried under Hadley $v$. Baxendale. Victoria was in the laundry and dyeing business. It owned a boiler, but it wanted a boiler of much greater capacity so that it could expand its business. In April 1946, Victoria contracted to buy a used boiler, with five times the capacity of its old one, from Newman, loaded by Newman on board a carrier at Newman's premises, delivery to take place on June 5. Newman employed a third person, $T$, to dismantle the boiler for shipping. On June 1, $T$ damaged the boiler in the process of dismantling it. As a result, Victoria did not receive delivery until November 8 , and sued Newman for lost profits during the period from June 5 to November $8 .{ }^{69}$

One of Victoria's claims was that during that period, if the boiler had been delivered in a timely fashion Victoria would have accepted highly lucrative dyeing contracts from the Ministry of Supply, which would have yielded profits of $£ 262$ per week. ${ }^{70}$ The court held that Victoria could recover some lost dyeing profits, because lost dyeing profits were reasonably foreseeable. However, the court went on, Victoria could not recover its actual, individualized, lost profits under the lost Ministry of Supply contracts, unless when the contract with Newman was formed, Newman was on notice of the prospect and terms of those contracts. Instead, Victoria could only recover "some general [standardized] ... sum for loss of business in respect of dyeing contracts to be reasonably expected."71

67. 156 Eng. Rep. 145 (Ex. D. 1854). The analysis in this Part draws on my Article, The Principle of Hadley v. Baxendale, 80 CALIF. L. REv. 563 (1992).

68. 2 K.B. 528 (C.A. 1949).

69. See id. at 529-30, 535 .

70. See id. at 535.

71. Id. at 543; accord RESTATEMENT SECOND, supra note $17, \S 351 \mathrm{cmt}$. b. 
In addition to being a standardized rule, the principle of Hadley $v$. Baxendale was a static rule. The static nature of that principle is brought out by comparing it with the principle of proximate cause, which governs the extent of recoverable damages in most areas of law outside contracts. ${ }^{72}$ Traditionally, the principle of Hadley $v$. Baxendale and the principle of proximate cause differed in two critical respects.

The first traditional difference between the two principles concerned the degree of probability required to make a wrongdoer liable for a given injury. It is not enough to say that a legal rule requires a showing of probability; there must also be at least a rough formulation of the level of probability that the rule requires. For example, one approach would be to require, as a condition to liability, that the probability of a given injury was more than marginal or not insignificant. A more demanding approach would require that the injury was more likely than not, or even was highly likely. Traditionally, the principle of Hadley $v$. Baxendale and the principle of proximate cause diverged widely in this regard. On the one hand, at least through the early part of the twentieth century it was unclear whether foreseebility was a factor in proximate cause. ${ }^{73}$ On the other, in its origin the principle of Hadley $v$. Baxendale required damages to be foreseeable at a more-likely-than-not or even highly likely level.

The second difference between the principle of Hadley v. Baxendale and the principle of proximate cause concerns time. Application of the principle of Hadley $v$. Baxendale is normally based on the information that the breaching party had at the time of contract-formation. In contrast, application of the principle of proximate cause normally depends on the circumstances that exist at the time of the wrong. Accordingly, the principle of Hadley v. Baxendale is static in nature, while the principal of proximate cause is dynamic in nature.

Over the years, a series of rationales have been proffered to justify the static aspect of the principle of Hadley $v$. Baxendale. As each new rationale has been shot down, a new one has popped up. For ease of exposition, in considering these rationales, I will call the breaching party the seller and the injured party the buyer. (The principle of Hadley $v$. Baxendale is typically applied in cases involving a breach by a seller, because usually a buyer's obligation is only to pay money, and a simple failure to pay money rarely results in consequential damages.)

The current rationale begins as follows: At the time of contract formation, a seller has a choice of the terms under which he will enter into a

72. See, e.g., U.C.C. $\$ 2-714$ (stating that damages for breach of warranty are governed by the principle of proximate cause); Grant GILmORE \& Charles L. Black, JR., ThE LAW OF AdMIRALTY 76 (2d ed. 1975) (explaining that marine insurance covers losses "proximately caused" by the peril insured against and claimed under).

73. See Fowler V. Harper, et al., The Law of Torts 20.5 (1986). 
contract and the precautions that he will take to ensure that he will be able to perform the contract. In making this choice, the seller can take account of information concerning the damages that might result from his breach. For example, if a seller knows that a particular buyer will probably incur consequential damages, the seller might charge the buyer a greater price, take greater-than-normal precautions to ensure his own performance, or both. Therefore, a buyer should be required to transmit information concerning his special circumstances to the seller by or at the time of contract formation, so that the seller can adjust his terms and precautions accordingly.

This rationale does not justify the principle of Hadley v. Baxendale.

In contracts for the sale of differentiated commodities, such as office buildings or custom-tailored software, the principle is normally mooted, because the precontract parley-specifications, quotations, preliminary discussions, and negotiations-normally puts the seller on notice of the buyer's special circumstances.

Homogeneous commodities are characteristically sold without the kind of precontract parley that in the case of differentiated commodities typically puts the seller on notice of the buyer's special circumstances. It is therefore true that in the case of homogeneous commodities the seller normally would not have reason to foresee that breach will likely cause consequential damages to any individual buyer unless the buyer communicates to the seller information concerning his special circumstances. In the case of homogeneous commodities, however, sellers can normally deal with the problem of consequential damages through probabilistic methods. Sellers of such commodities typically sell in high volumes and develop an extensive claims experience. This experience allows sellers to construct a probability distribution of potential claims. Therefore, although such sellers might not know whether, in the event of breach, any individual buyer will likely incur supranormal damages (either general or consequential), they will usually know that given percentages of their buyers will almost certainly incur supranormal damages within a series of ranges. Accordingly, the seller can predict damages outcomes taken in the aggregate, and can set an equilibrium price that reflects aggregate damages. Thus a high-volume seller of homogeneous commodities can reliably price and plan for supranormal damages, even in the absence of information transmitted at the time of contract formation, by setting an equilibrium price and level of precaution that takes into account, on a weighted basis, all potential damages from breach. Alternatively, the seller can deal with supranormal damages contractually, either by limiting its liability outright or by offering buyers a menu of lower prices and lower seller liability or higher prices and higher seller liability. 
Furthermore, high-volume sellers of homogeneous commodities are often unlikely to take special precautions even when they know that a buyer presents a high risk of supranormal damages. The critical issue here is the probable rate of breach. Suppose that a seller breaches only one out of every 500 contracts, and that only a small portion of the seller's breached contracts result in consequential damages. Such a seller is highly unlikely to incur the expense of setting up separate facilities and processes just to deal with the occasional consequential-damages buyer. For example, high-volume carriers, such as airlines, express-mail handlers, and household movers, routinely limit their liability for loss unless the seller pays a special premium. Therefore, these carriers know precisely which shipments will involve supranormal damages. However, casual empirical research indicates that (as is to be expected) such carriers normally take no greater precautions in transporting high-value shipments, for the loss of which they have specifically agreed to pay supranormal damages, than for transporting shipments as to which their liability is limited. ${ }^{74}$

Another rationale for the principle of Hadley v. Baxendale remains: even if sellers can protect themselves by equilibrium pricing, under such pricing normal-damages buyers will inefficiently cross-subsidize supranormal-damages buyers, because the higher cost of selling to the latter will be reflected in higher prices charged to the former. The principle of Hadley $v$. Baxendale allows the seller to prevent this cross-subsidization, by forcing supranormal-damages buyers to reveal themselves.

The principle of Hadley v. Baxendale, however, is a clumsy and ineffective tool to deal with this problem. To begin with, at best the principle forces only a subset of supranormal-damages buyers to reveal themselves, that is, the subset of consequential-damages buyers. Even buyers who will not suffer consequential damages may have supranormal damages. For example, an actor who ships high-value goods will have high general damages if the carrier negligently injures or loses the goods. Then too, the principle of Hadley $v$. Baxendale does not (or should not) require the buyer to reveal the extent of his consequential damages, but only the prospect of such damages.

Furthermore, a seller who wants to make use of information transmitted to it under the principle of Hadley $v$. Baxendale normally has to incur costs, first for retransmitting the buyer's information from the seller's frontline employees to its risk managers, and then for evaluating and acting on the information. If a seller deals in high volumes, and the probable rate

74. Telephone interviews by Daniel A. Saunders with Jim Hanon, Director of Underwriting for United Van Lines; Trudy Atkinson, Customer Service Agent for Federal Express; Tina McGuire of Emery Air Freight; Alice Rogers of American Airlines; and representatives of Airborne, Pan Am, United, and TWA. 
of breach is low, which seems typical, the cost to the seller of processing and utilizing such information would almost invariably exceed the expected value of utilizing such information, because if breach seldom occurs, almost all of the costs will be wasted. Observation suggests that sellers of homogenous commodities typically do not adopt such strategies. For example, it is reasonably clear that information about a buyer's special circumstances that the buyer transmits to the front-line sales or clerical personnel of sellers of relatively homogenous commodities will normally travel no further, and will therefore have no impact on the seller's conduct. Thus in practice the principle of Hadley v. Baxendale will usually not lead to the prevention of cross-subsidization between buyers, just as in practice the principle will usually not lead to greater precaution by sellers.

This does not mean that sellers do not want to deal with the problem of exposure to supranormal damages and the problem of buyer crosssubsidization. They do. But they do not deal with those problems through the principle of Hadley $v$. Baxendale. They deal with those problems through contract. In particular, sellers can, and routinely do, deal with both problems either by limiting their liability, or by providing the buyer with a liability-and-price menu that allows the buyer to select her own level of damages for the seller's breach, and pay a commensurate price.

In short, under modern business and contracting practice, the principle of Hadley v. Baxendale is not required either to achieve efficient pricing or efficient precaution, or to prevent cross-subsidization. All these goals can be and are achieved even without that principle, by probabilistic methods of doing business and by contracting. Given these techniques, the dynamic principle of proximate cause, coupled with the power to contractually limit liability, is a more efficient regime than the static principle of Hadley $v$. Baxendale.

To begin with, under the primciple of Hadley $v$. Baxendale the burden is on buyers to communicate information about their special circumstances. In contrast, under the principle of proximate cause the burden is on sellers to contractually limit damages. A default rule that puts the burden on sellers to contractually limit damages is preferable to a default rule that puts the burden on buyers to disclose their special circumstances, because sellers as a class are in a much better position than buyers to determine how to most efficiently couple price-and-liability choices, and because buyers have a legitimate interest in not disclosing facts concerning their businesses.

Furthermore, many buyers-particularly, but not exclusively, consumers-do not know the principle of Hadley v. Baxendale. Such buyers will often fail to communicate information about their special circumstances because such communication will seem unreasonable, partly because the buyers realize that the information will be disregarded by the 
frontline salespeople and clerks with whom they deal. In contrast, under a proximate cause default rule buyers would not have to know the law, because the seller's contract will delineate the seller's basic liability and the buyer's alternative price-and-liability choices.

Moreover, in most cases costs under a proximate cause default rule will be much lower than costs under the principle of Hadley $v$. Baxendale. To take advantage of the efficiency effects of that principle, the seller must train its front-line personnel to screen information given to them by buyers and to then to pass on this information to higher-ups, who must in turn evaluate the information to decide on what terms to contract. To transact around the principle, the buyer must determine what information is relevant to the seller concerning the buyer's special circumstances, and then transmit that information. In contrast, under a proximate cause regime the seller only needs to make a one-time (or at worst periodic) investment in determining whether and how to limit damages or what price-and-liability menu it should adopt, and the buyer need only decide whether to accept the seller's limitation on dainages or which alternative on the seller's menu is optinal. Furthermore, unlike the principle of Hadley v. Baxendale, limitations on dainages and price-and-liability menus protect the seller against supranormal dainages, not only against consequential damages.

Finally, because the principle of Hadley $v$. Baxendale is static, it is inconsistent with the theory of efficient breach. Under that theory, the decision to perform or to breach a contract should depend dynamically on the costs and benefits of breach to both parties at the time the decision to breach is made. Under the principle of Hadley $v$. Baxendale, however, the seller, in determiming whether to breach, can disregard all reasonably foreseeable costs except those that he had reason to know were probable at the time the contract was made. Therefore, the theory of efficient breach suggests that the principle of Hadley $v$. Baxendale is inefficient insofar as it allows the seller, in deciding whether to breach, to disregard reasonably foreseeable and even known costs that will result from breach.

As regards the required standard of foreseeability the general principle of proxinuate cause and the special principle of Hadley $v$. Baxendale have been converging in modern times. On the one hand, the element of foreseeability has now been incorporated into proximate cause. On the other hand, the level of probability required under the principle of Hadley $v$. Baxendale has been steadily eroding. For example, in Koufos $v . C$. Czarnikow, Ltd. ${ }^{75}$ decided by the House of Lords, the Law Lords' opinions approved such tests as "liable to result," "real danger," and "serious possibility." In some cases, the test of foreseeability is diluted even further. For exainple, in Hector Martinez \& Co. v. Southern Pacific Transportation Co., the court said that the plaintiff "need only demonstrate that his harm

75. 1 App. Cas. 350 (H.L. 1969). 
was not so remote as to make it unforeseeable at the time of contracting."76 All of these formulations require a level of probability that is much less demanding than the traditional more-likely-than-not or highly-likely requirement. $^{77}$

In contrast to the convergence of standards of foreseeability, the divergence concerning the time at which the principle of proximate cause and the principle of Hadley $v$. Baxendale are applied remains sigmificant. The principle of proximate cause is apphed dynamically, at the time of the injury. With rare exceptions, however, the principle of Hadley $v$. Baxendale is still applied on a static basis, at the time of contract-formation. This approach may suffice where the breach is not opportunistic and the seller did not know, at the time of breach, that the mjury to the buyer would significantly exceed the benefits to the seller. Where, however, the seller knew of that disproportion and nevertheless engaged in a deliberate, opportunistic breach-intended to save money at the buyer's expense - the foreseeability principle should be applied dynamically, at the time of breach.

This is not now the law. However, several cases have applied a proximate-cause analysis in contract cases by treating a breach as fraudulent or tortious. ${ }^{78}$ Article 1997 of the Louisiana Civil Code takes a more general approach. That Article provides that "an obligor in bad faith is liable for all of the damages, foreseeable or not, that are a direct consequence of failure to perform." 79 For example, iu Bond $v$. Broadway, ${ }^{80}$ $D$ contracted to purchase $P$ 's residence, Home 1 , for $\$ 30,000$ cash and the assumption of $P$ 's mortgage. In reliance on his contract with $D, P$ contracted to purchase Home 2 to take the place of Home 1. On $D$ 's final inspection of Home 1, however, he claimed that it contained several defects, and refused to purchase it. As a result, $P$ was required to take out a second mortgage on Home 1 to provide the down payment for Home 2. Eventually, $P$ sold Home 1 to $T$. The court found that $D$ had breached the contract with $P$ in bad faith: the alleged defects were minor and fixable, and were raised merely as a ruse to escape the contract. The court therefore held that $D$ was liable under Article 1997 for all of $P$ 's damages, whether or not they were foreseeable at the time the contract was made. These damages imcluded the additional payments $P$ was required to make on his first

76. 606 F.2d 106, 110 (5th Cir. 1979).

77. See, e.g., Wullschleger \& Co. v. Jenny Fashions, Inc., 618 F. Supp. 373 (S.D.N.Y. 1985); Prutch v. Ford Motor Co., 618 P.2d 657 (Colo. 1980); Miles v. Kavanaugh, 350 So. 2 d 1090 (Fla. Dist. Ct. App. 1977); Midland Hotel Corp. v. Reuben H. Donnelley Corp., 515 N.E.2d 61 (Ill. 1987); R.I. Lampus Co. v. Neville Cement Prods. Corp., 378 A.2d 288 (Pa. 1977).

78. See, e.g., Marshall Durbin Farms, Inc. v. Landers, 470 So. $2 d 1098$ (Ala. 1985); Rawlings v. Apodaca, 726 P.2d 565 (Ariz. 1986).

79. LA. Civ. Code ANN. art. 1997 (West 2000).

80. 607 So. $2 d 865$ (La. Ct. App. 1992). 
mortgage on Home 1 before that mortgage was assumed by $T$, interest on $P$ 's second mortgage on Home 1 , and the closing costs for the sale of Home 1 to $T$.

Of course, Louisiana is a Civil Code, not a common law, jurisdiction. It is worth remembering, however, that the common law borrowed from the French Civil Code in adopting the principle of Hadley v. Baxendale. During the course of the argument in that case, Baron Parke said:

The sensible rule appears to be that which has been laid down in France, and which is declared in their code - Code Civil, . . 1149, 1150,1151 , and which is thus translated in Sedgwick: "The damages due to the creditor consist in general of the loss that he has sustained, and the profit which he has been prevented from acquiring, subject to the modifications hereinafter contained. The debtor is only liable for the damages foreseen, or which might have been foreseen, at the time of the execution of the contract, when it is not owing to his fraud that the agreement has been violated. Even in the case of non-performance of the contract, resulting from the fraud of the debtor, the damages only comprise so much of the loss sustained by the creditor, and so much of the profit which he has been prevented from acquiring, as directly and immediately results from the non-performance of the contract. ${ }^{81}$

"Fraud," in the italicized phrase from Sedgwick's translation, is a translation of the word " $d o l$ " in French Civil Code Article $1150{ }^{82}$ In Sedgwick's day, as often in ours, the term "fraud" encompasses more than deception. Thus one modern translation renders "dol" as willfulness. ${ }^{83}$ Similarly, the predecessor of Louisiana Civil Code Article 1997, which was based on French Civil Code Article 1150, used the term "fraud or bad faith," and Article 1997 itself uses only the term "bad faith."

In short, Hadley v. Baxendale was in part an attempt to transplant an idea from the French Civil Code to the common law. However, the operation was botched, because the court left behind an important part of the idea. If the principle of Hadley $v$. Baxendale is to be retained, the idea of the principle should be made whole by reinstituting the bad faith exception where a breach is opportunistic. Indeed, even if that exception is not reinstituted as part of the principle of Hadley $v$. Baxendale, it should be

81. Hadley v. Baxendale, 156 Eng. Rep. 145, 147-48 (Ex. D. 1854) (emphasis added). See also Franco Ferrari, Comparative Ruminations on the Foreseeability of Damages in Contract Law, $53 \mathrm{LA}$. L. REv. 1257 (1993).

82. Article 1150 provides: 'Le débiteur n'est tenu que des dommages et intérêts qui ont été prévus ou qu'on a pu prévoir lors du contrat, lorsque ce n'est point par son dol que l'obligation n'est point exécutee." C. Clv. art. 1150 (Fr.).

83. C. Civ. art. 1150 (Fr.), translated in The French Civil Code, Revised Edition 223 (John H. Crabb trans., Rothman \& Co. 1995).

84. LA. Civ. Code ANN. art. 1997. 
applied under the general principle that contracts must be performed in good faith.

\section{Liquidated Damages ${ }^{85}$}

It is a basic principle of contract law that contractual provisions that liquidate damages for breach are not enforceable according to their terms, as are most other provisions of a bargain, but instead are reviewed with special scrutiny. I will call this special-scrutiny rule the liquidated damages principle.

The formulations of this principle vary, but typically a liquidated damages provision is enforceable only if the amount fixed is a reasonable estimate of the actual loss. ${ }^{86}$ This requirement, however, is profoundly ambiguous. It may mean either that the liquidated amount must be a reasonable estimate of probable loss, looking forward from the time the contract is made; that the liquidated amount must be a reasonable estimate of the loss that is actually sustained; or both. The classical view of the requirement was that a liquidated damages provision need only satisfy the forward-looking standard. Under this view, the liquidated damages principle was static, because its applicability depended entirely on circumstances existing at the time of contract formation. Later events-in particular, the actual loss suffered-were deemed irrelevant, at least in theory. Today, the approach to this issue has changed, and the courts are applying the liquidated damages principle dynamically, with a second-look approach that takes account of the actual loss.

Many have questioned the principle that courts should give special scrutiny to liquidated damages provisions. Although the arguments vary, Judge Posner's critique in Lake River Corp. v. Carborundum Co ${ }^{87}$ is fairly typical: "[T] he parties (always assuming they are fully competent) will, in deciding whether to include a penalty clause in their contract, weigh the gains against the costs ... and will include the clause only if the benefits exceed those costs ...."88 Charles Goetz and Robert Scott make a similar critique: "There is no reason to presume that liquidated damages provisions are more susceptible to duress or other bargaining aberrations than other contractual allocations of risk." 89

85. The analysis in this Part draws on my Article, The Limits of Cognition and the Limits of Contract, 47 Stan. L. Rev. 211 (1995).

86. Courts label liquidated damages provisions that do not satisfy this requirement "penalties" and decline to enforce them. See, e.g., Wasserman's Inc. v. Middletown, 465 A.2d 100 (1994).

87. 769 F.2d 1284 (7th Cir. 1985).

88. Id. at 1289.

89. Charles J. Goetz \& Robert E. Scott, Liquidated Damages, Penalties and the Just Compensation Principle: Some Notes on an Enforcement Model and a Theory of Efficient Breach, 77 Colum. L. Rev. 554, 592 (1977). 
Most critiques, like those of Posner and Goetz and Scott, have an implicit or explicit three-part structure: (1) They begin by assuming that the major justification for the principle that liquidated damages provisions should be given special scrutiny is that such provisions lend themselves to blameworthy exploitation of one party by the other, and consequent onesidedness, in a way that other types of contract provisions do not. (2) They then argue that this justification will not hold. (3) They conclude that the special principle is therefore unjustified. So, for example, Goetz and Scott argue that the principle of special scrutiny of liquidated damages provisions arose in a historical context in which protections against fraud and duress were not available. Given the modern development of unconscionability as a unifying unfairness principle, they suggest, the law should simply collapse the treatment of liquidated damages into that principle..$^{90}$

The assumption that special scrutiny of liquidated damages provisions is justified primarily by a special potential for blameworthy exploitation and one-sidedness does reflect the courts' rhetoric, which is cast in terms of whether or not such provisions are "penalties," and therefore suggests a concern with advantage-taking and oppression. This assumption also reflects the static interpretation of the liquidated damages principle, because whether a liquidated damages provision involved blameworthy exploitation and one-sidedness is evidenced by whether the provision was unfair, in some way, when agreed to. In fact, however, the justification for the special scrutiny of liquidated damages provisions is not that such provisions are specially amenable to blameworthy exploitation and onesidedness, but that such provisions are systematically likely to reflect the limits of human cognition.

Classical contract law was based on a rational-actor model of psychology. Under this model, actors who make decisions in the face of uncertainty rationally maximize their subjective expected utility, with all future benefits and costs properly discounted to present value. A great body of theoretical and empirical work in cognitive psychology within the last thirty or forty years has shown that rational-actor psychology often lacks explanatory power. ${ }^{91}$ Although rational-actor psychology is the foundation of the standard economic model of choice, the empirical evidence shows that this model often diverges from the actual psychology of choice, due to limits of cognition. As Amos Tversky and Daniel Kahneman point out, expected-utility (rational-actor) theory "emerged from a logical analysis of games of chance rather than from a psychological analysis of

90. See id. at 593-94; see also Alan Schwartz, The Myth that Promisees Prefer Supracompensatory Remedies: An Analysis of Contracting for Damage Measures, 100 YALE L.J. 369, 370 (1990).

91. See Thomas S. Ulen, Cognitive Imperfections and the Economic Analysis of Law, 12 HAMLINE L. REV. 385 (1989). 
risk and value: The theory was conceived as a normative model of an idealized decision maker, not as a description of the behavior of real people." ${ }^{.92}$

In contrast to rational-actor psychology, modern cognitive psychology recognizes various limits of cognition. For purposes of contract law, three kinds of limits of cognition are especially salient: bounded rationality, irrational disposition, and defective capability.

\section{Bounded Rationality}

To begin with, an actor may not even consider the action that would maximize his utility, because actors limit their search for and their deliberation on alternatives. If the costs of searching for and processing (evaluating and deliberating on) information were zero, and human information-processing capabilities were perfect, then an actor contemplating a decision would make a comprehensive search for relevant information, would process perfectly all the information he acquired, and would then make the best possible substantive decision-the decision that, as of the time made, was better than all the alternative decisions the actor might have made if he had complete knowledge and perfect processing abilities, and which would therefore maximize the actor's subjective expected utility. I will call such a decision an optimal substantive decision.

In reality, of course, searching for and processing information does involve costs, in the form of time, energy, and perhaps money. Most actors either do not want to expend the resources required for comprehensive search and processing or recognize that comprehensive search and processing would not be achievable at any realistic cost, and instead choose some degree of rational ignorance. Furthermore, our abilities to process information and solve problems are constrained by limitations of computational ability, ability to calculate consequences, ability to organize and utilize memory, and the like. ${ }^{93}$ Hence, actors will often process imperfectly even the information they do acquire. Such imperfections in human processing ability increase as decisions become more complex and involve more permutations. ${ }^{94}$

Accordingly, human rationality is normally bounded by limited information and limited information-processing..$^{95}$

92. Amos Tversky \& Daniel Kahneman, Rational Choice and the Framing of Decisions, $59 \mathrm{~J}$. Bus. S251 (1986).

93. See James G. March, Bounded Rationality, Ambiguity, and the Engineering of Choice, 9 Bell J. ECoN. 587, 590 (1978); see also Herbert A. Simon, Rational Decisionmaking in Business Organizations, 69 AM. EcON. REv. 493, 502-03 (1979) (sketching the development of the theory of the strategies that actors use under bounded rationality).

94. See James G. March \& Herbert A. Simon, Organizations 171 (1st ed. 1958).

95. See Herbert A. Simon, Administrative Behavior 79-109 (3d ed. 1976). 


\section{Irrational disposition}

Next, actors are unrealistically optimistic as a systematic matter. ${ }^{96}$ (Lawyers do not realize this, because they are trained to be systematically pessimistic.) The dispositional characteristic of undue optimism is strikingly illustrated in a study by Lynn Baker and Robert Emery, appropriately titled, When Every Relationship Is Above Average. ${ }^{97}$ Baker and Emery asked people who were about to get married to report on their own divorce-related prospects as compared to the divorce-related prospects of the general population. The disparities between perceptions as to the general population and expectations as to self were enormous, and were almost invariably in the direction of optimism. For example, the respondents correctly estimated that fifty percent of American couples will eventually divorce. In contrast, the respondents estimated that their own chance of divorce was zero. ${ }^{98}$ Similarly, the respondents' median estimate of how often spouses pay court-ordered alimony was that forty percent paid. In contrast, 100 percent of the respondents predicted that their own spouse would pay all court-ordered alimony. ${ }^{99}$

\section{Defective Capability}

Finally, cognitive psychology has established that actors use certain decision-making rules (heuristics) that yield systematic errors: "[T]he deviations of actual behavior from the normative model are too widespread to be ignored, too systematic to be dismissed as random error, and too fundamental to be accommodated by relaxing the normative system."100 For example, actors make decisions on the basis of data that is readily available to their memory, rather than on the basis of all the relevant data. In particular, actors systematically give undue weight to instantiated evidence as compared to general statements, to vivid evidence as compared to pallid evidence, and to concrete evidence as compared to abstract evidence. ${ }^{101}$ Similarly, actors are systematically insensitive to sample size, and erroneously take small samples as representative samples.

Another such defect in capability concerns the ability of actors to make rational comparisons between present and future states. For example, the sample consisting of present events is often wrongly taken to be

96. See Neil D. Weinstein, Undue Optimism About Future Life Events, 39 J. PERsonalitY AND Social Psychol. 806 (1980).

97. Lynn A. Baker \& Robert C. Emery, When Every Relationship Is Above Average: Perceptions and Expectations of Divorce at the Time of Marriage, 17 LAW AND HuM. BEHAV. 439 (1993).

98. See id. at 443 .

99. See id.

100. Tversky \& Kahneman, supra note 92, at S252.

101. See Robyn Dawes, Rational Choice in an UnCertain World 92-94 (1988). 
representative, and therefore unduly predictive of future events. ${ }^{102}$ Actors also systematically give too little weight to future benefits and costs as compared to present benefits and costs. ${ }^{103}$ Thus Martin Feldstein concludes that "some or all individuals have, in Pigou's ... words, a 'faulty telescopic faculty' that causes them to give too little weight to the utility of future

consumption."104

A defect of capability related to faulty telescopic faculties is the systematic underestimation of risks. ${ }^{105}$ Based on the work of cognitive psychologists, Kenneth Arrow observes that "[i]t is a plausible hypothesis that individuals are unable to recognize that there will be many surprises in the future; in short, as much other evidence tends to confirm, there is a tendency to underestinate uncertainties." 106 In fact, empirical evidence shows that actors often not only underestimate but ignore low-probability risks.

These defects in capability are also closely related to and interact with the dispositional problem of unrealistic optimism. If actors are unrealistically optimistic, they will systematically underestimate risks. If actors systematically underestimate risks, they will be unrealistically optimistic. These defects in capability are also closely related to bounded rationality. The problems of availability and representativeness, for instance, would not even come into play if search and processing were unbounded. Only where actors rely on selective, incomplete information does undue emphasis on readily available and unrepresentative data pose a problem.

The limits of cognition have a special bearing on liquidated damages provisions.

To begin with, bounded rationality and rational ignorance play an important role. Contracting parties normally will find it relatively easy to evaluate proposed performance terms, such as subject matter, quantity, and price. In contrast, at the time a contract is made it is often impracticable, if not impossible, to imagine all the scenarios of breach. Similarly, the inherent complexity of determining the application of a liquidated damages provision to every possible breach scenario often is likely to exceed actors' calculating capabilities.

Even on the doubtful assumption that a party could imagine all breach scenarios and calculate the application of a liquidated damages provision to every possible breach, the benefits of extensive search and

102. See Kenneth Arrow, Risk Perception in Psychology and Economics, 20 J. ECON. INQUIRY 1, 5 (1982).

103. See Martin Feldstein, The Optimal Level of Social Security Benefits, 100 Q. J. EcoN. 303, 307 (1985).

104. Id. at 307 (quoting Pigou).

105. See Thomas H. JACKSON, THE Logic AND Limits OF BANKRUPTCY LAW 237-40 (1986).

106. Arrow, supra note 102, at 5. 
information processing on these issues will often seem to be very low as compared to the costs. A party who contracts to buy or sell a commodity normally expects to perform. Accordingly, the benefits to the party of deliberating very carefully on performance terms-terms that specify what performance the party is required to render-are compelling, and the costs of such deliberation usually do not outweigh the benefits. ln contrast, a party will often not expect that a liquidated damages provision will ever come into play against him, partly because he intends to perform, and partly because experience will tell him that in general there is a high rate of performance of contracts. For example, if contracts are performed at least ninety-five percent of the time (which observation suggests is likely), all the costs of processing the more remote applications of a liquidated damages provision would have to be taken into account, but the benefits of such processing would have to be discounted by ninety-five percent. The resulting cost-benefit ratio will often provide a substantial disincentive for processing every possible application of a liquidated damages provision, even if it were in fact possible to imagine every such scenario. As a result, contracting parties are often likely to not think through liquidated damages provisions, and are therefore often unlikely to fully understand the implications of such provisions.

The problem of irrational disposition also bears significantly on liquidated damages provisions. Because actors tend to be unrealistically optimistic, a contracting party probably will believe that his performance is more likely, and his breach less likely, than is actually the case. Accordingly, unrealistic optimism will reduce even further the deliberation that actors give to liquidated damages provisions.

Finally, defective capabilities have particular relevance to liquidated damages provisions. The availability heuristic may lead a contracting party to give undue weight to his present intention to perform, which is vivid and concrete, as compared with the abstract possibility that future circumstances may compel him to breach. Because a contracting party is likely to take the sample of present evidence as unduly representative of the future, he is apt to overestimate the extent to which his present intention to perform is a reliable predictor of his future intentions. Because actors have faulty telescopic faculties, a contracting party is likely to overvalue the benefit of the prospect of performance, which will normally begin to occur in the short term, as against the cost of the prospect of a breach, which will typically occur, if at all, only down the road. Because actors tend to underestimate risks, a contracting party is likely to underestimate the risk that a liquidated damages provision will take effect.

The cases involving liquidated damages provisions provide dramatic evidence of how such provisions are peculiarly subject to the limits of cognition. A good example is the landmark English case Kemble $v$. 
Farren. ${ }^{107}$ In this case, a performer had agreed to be the principal comedian at Covent Garden Theatre during the ensuing four seasons and to fully conform to the theater's usual regulations. The theater had agreed to pay the actor $31.6 \mathrm{~s}$. 8d. every night the theater was open during the four seasons. The contract also provided that if either party failed to fulfill the agreenient or any part thereof, that party would pay the other $£ 1000$. The actor breached the contract, and the theater sued for liquidated damages. ${ }^{108}$

The court began by noting that liquidated damages provisions can serve valid purposes: "In nrany cases, such an agreement fixes that which is almost inupossible to be accurately ascertained; and in all cases, it saves the expense and difficulty of bringing witnesses to that point." 109 Nevertheless, the court held that the provision in question was unenforceable. In reaching this conclusion, the court pointed out the bizarre ways in which the provision could operate:

[T] party. If, therefore, on the one hand, the Plaintiff had neglected to make a single payment of $31.6 \mathrm{~s} 8 \mathrm{~d}$. per day, or on the other hand, the Defendant had refused to conform to any usual regulation of the theatre, however minute or unimportant, it must have been contended that the clause in question, in either case, would have given the stipulated damages of $1000 £ .{ }^{110}$

It seems scarcely likely that the parties in Kemble intended their liquidated damages provision to apply to every conceivable failure to perform. Rather, it is almost certain that as a result of the limits of cognition, the parties failed to think through the scenarios under which the provision would apply.

The Lake River case, ${ }^{11}$ which occasioned Judge Posner's critique of the principle governing liquidated damages provisions, provides a similar example. Carborundum had made a contract with Lake River concerning Ferro Carbo, an abrasive powder produced by Carborundum for use in making steel. Under the contract, Carborundum would ship Ferro Carbo in bulk to Lake River. Laker River, in turn, would bag the Ferro Carbo and distribute the bagged product to Carborundum's custoniers. To bag the Ferro Carbo, Lake River was required to install a new bagging system at a cost of $\$ 89,000$. To ensure recovery of the cost of the bagging system, Lake River insisted on a nininum-quantity-guarantee provision. The provision required Carborundum to ship 22,500 tons of Ferro Carbo to Lake River for bagging during the initial three-year term of the contract. If Carborundum failed to meet this minimum, Carborundum was to pay for

107. 6 Bing. 141, 19 Eng. Rep. 71 (C.P. 1829).

108. See id. at 141 .

109. Id. at 148 .

110. Id.

111. Lake River Corp. v. Carborundum Co., 769 F.2d 1284 (7th Cir. 1985). 
the shortfall at the then-prevailing bagging rate under the contract. As Judge Posner recognized, this was essentially a liquidated damages provision. ${ }^{112}$

After the contract was signed in 1979, the demand for domestic steel, and hence for Ferro Carbo, fell dramatically. As a result, by the time the initial three-year term expired in late 1982, Carborundum had shipped only 12,000 of the 22,500 tons it had guaranteed. Lake River demanded payment of $\$ 241,000$ under the liquidated damages provision.

The court held that the provision was unenforceable. ${ }^{113}$ Judge Posner pointed out that if Carborundum had shipped the full guaranteed quantity, Lake River would have made a profit of $\$ 107,000$, net of all expenses that Lake River would have incurred, including the cost of the bagging system. He then demonstrated the bizarre way the provision operated under various scenarios of breach. For example, if Carborundum had breached the contract before shipping any Ferro Carbo, and the liquidated damages provision was enforced, Lake River would make a profit of $\$ 444,000$, or niore than four times the profit it would have made if Carborundum had performed, even assuming the bagging system had a value of zero at that point. If, as actually occurred, Carborundum breached after fifty-five percent of the Ferro Carbo had been shipped, and the liquidated-damages provision was enforced, Lake River would make a profit of $\$ 260,000$, or twoand-one-half times the profit it would have made if Carborundum had performed. In short, if the provision was enforceable it would generate damages to Lake River ranging up to $434 \%$ of the profits that Lake River stood to make by full performance. ${ }^{114}$

It is almost inconceivable that the parties understood and intended that the provision would operate in that way, or that Carborundum, undoubtedly the stronger party, would have agreed to the provision if it had understood how the provision operated. The overwhelming likelihood is that, as in Kemble, neither Carborundum nor Lake River managed to think through how the provision would operate under various breach scenarios because of the special bite of the limits on cognition in the case of liquidated damage provisions.

112. See id. at 1288 ("The hardest issue ... is whether the formula in the minimum-guarantec clause imposes a penalty ... or is merely an effort to liquidate damages.").

113. See id. at 1290 .

114. See id. at 1290-91. If the liquidated damages provision was enforced upon a breach at any one of various times between the beginning of Lake River's performance and nearly the end, it would have generated a windfall ranging from $130 \%$ to $400 \%$ of Lake River's expected contract profits assuming that the bagging system had no value apart from the contract. If the bagging system was worth as little as $\$ 20,000$ at the time of breach, the windfall liquidated damages would have ranged from $150 \%$ to $434 \%$ of expected profits. See id. 
Cases like Kemble and Lake River, which are not unique, ${ }^{115}$ forcefully illustrate that as a result of the limits of cognition, the premise underlying the bargain principle, that a contracting party will act with full cognition to rationally maximize his subjective expected utility, does not apply to liquidated damages provisions. Since the premise does not apply, neither should the principle itself. Rather, special scrutiny of liquidated damages provisions is justified because such provisions are subject to the limits of cognition in a special way.

This cognitive explanation of the liquidated damages principle is important because it not only justifies the special scrutiny of liquidated damages provisions, but shapes the form that the special scrutiny should take. Recall that a critical element of the liquidated damages principle is a requirenent that a liquidated damages provision is enforceable only if the amount fixed in the provision is a reasonable estimate of the actual loss, but that the principle leaves open whether this element is to be applied on a static, purely time-of-the-contract, or a dynamic, second-look basis.

Classical contract law adopted a static, purely time-of-the-contract approach to this issue. As pointed out above, this approach was consistent with the position that the justification for giving special scrutiny to liquidated damages provisions is that such provisions are especially subject to blameworthy exploitation and one-sidedness, because whether there was blameworthy exploitation and one-sidedness should be judged as of the time the contract was niade. ${ }^{116}$

In contrast, the cognitive justification for special scrutiny of liquidated damages provisions suggests a dynamic, second-look approach that compares liquidated damages with the actual loss, because a gross discrepancy between forecast and result suggests that the liquidated damages provision was a product of limited or defective cognition. Under a cognitive approach to the liquidated damages principle, therefore, courts should formulate and apply the principle dynamically, as follows: If, in the breach scenario that has actually occurred, liquidated damages are significantly disproportionate to real losses (that is, losses in fact, not simply legal

115. See, e.g., Meltzer v. Old Furnace Dev. Corp., 254 N.Y.S.2d 246, 249 (1964) (invalidating mortgage provisions that rendered mortgagors liable for an additional $25 \%$ of mortgage debt for default, because a default of one day would result in the same damages as a default of several months); Alvord v. Banfield, 166 P. 549, 552 (Or. 1917) (holding that a lease provision requiring payment of $\$ 2500$ for any breach, regardless of magnitude, is a penalty clause); Stewart v. Basey, 245 S.W.2d 484, 487 (Tex. 1952) (holding that a damage stipulation that "was not carefully drawn" should not bind the parties).

116. See, e.g., United States v. Bethlehem Steel Co., 205 U.S. 105, 119-21 (1907) (upholding a contract provision, negotiated during a war and reasonable ex ante, stipulating damages for late delivery of guns, even though the end of the war prior to the delivery date eliminated the possibility of losses); see also Southwest Eng'g Co. v. United States, 341 F.2d 998, 1003 (8th Cir. 1965) (holding that the situation at the time of the contract is controlling in determining the reasonableness of liquidated damages). 
damages), the provision is unenforceable unless it is established that the parties had a specific and well-thought-through intention that the provision apply in a scenario like the one that actually occurred.

Despite the classical emphasis on the time-of-the-contract approach, the second-look approach supported by the cognitive justification seems to be emerging law. As a predictive matter, it is highly likely that even courts that profess a purely time-of-the-contract approach will be influenced by the loss that was actually sustained. ${ }^{117}$ As a descriptive matter, the case law is evolving toward a second-look approach, ${ }^{118}$ although the cases are not completely consistent. ${ }^{119}$ Similarly, Restatement Second states that "If, to take an extreme case, it is clear that no loss at all has occurred, a provision fixing a substantial sum as damages is unenforceable." 120

117. Sweet concludes that when courts decide whether to enforce a liquidated damages clause, "though the announced test is look-forward, what counts is the convenience and efficiency by which actual damages can be measured at trial." Justin Sweet, Liquidated Damages in California, 60 CALIF. L. REV. 84, 136 (1972). Sweet further concludes that when directly faccd with the question, most California courts will not knowingly cnforce a liquidated damages clause where there is no actual damage. See id. at 138; see also Freedman v. Rector, 230 P.2d 629, 632 (Cal. 1951) (holding that any provision that leads to forfeiture without regard to the actual damage suffered would be an unenforceable penalty).

118. See, e.g., Colonial at Lynnficld, Inc. v. Sloan, 870 F.2d 761, 765 (1st Cir. 1989) (invalidating a liquidated damages provision because no actual damage occurred, although the damage estimate was reasonable at the time the contract was made); Northwest Fixture Co. v. Kilbourne \& Clark Co., 128 F. 256, 261 (9th Cir. 1904) (denying recovery under a liquidated damages provision to a company that sustaincd no actual damages); Vines v. Orchard Hills, Inc., 435 A.2d 1022, 1028 (Conn. 1980) (considering actual damages at the time of breach in determining the validity of a liquidated damages clause); Norwalk Door Closcr Co. v. Eagle Lock \& Screw Co., 220 A.2d 263, 268 (Conn. 1966) (invalidating liquidated damages provision because no actual damages occurred); Huntington Coach Corp. v. Board of Educ., 372 N.Y.S.2d 717, 719 (App. Div, 1975) (refusing to enforce $\$ 100$-per-day liquidated damages for failure to provide school-bus services to a school district for a five-day period where the district had not sought other transportation and the bus company had not billed the district for the period), aff'd, 357 N.E.2d 1017 (1976); Kenneth W. Clarkson et al., Liquidated Damages $v$. Penalties: Sense or Nonsense?, 1978 W1S. L. REv. 351, 380 ("In most cascs that declared actual damages to be irrelevant ... the clauses were reasonable ex ante and, given the difficulty in measuring actual damages, not unrcasonable ex post. Further, in numerous cases where the clause was clearly no longer reasonable ex post, the court refused enforcement.") (footnotes omittcd); Schwartz, supra note 85 , at 369 ("Courts will not enforce liquidated damage clauses when [the] stipulated sum exceeds ... the actual harm that breach turned out to cause."); see also Massman Constr. Co. v. City Council, 147 F.2d 925, 927 (5th Cir. 1945) (refusing to allow liquidated damages in part because the city did not suffer any damages from bridge completion delays as a result of even longer delays in road construction). But cf. California \& Hawaiian Sugar Co. v. Sun Ship, Inc., 794 F.2d 1433, 1435-37 (9th Cir. 1986) (permitting liquidated damages although plaintiff suffered minimal actual damages due to a concurrent breach by a third party); McCarthy v. Tally, 297 P.2d 981, 987 (Cal. 1956) (holding that no actual damage is necessary in order to recover under a liquidated damages provision); Leeber $v$. Deltona Corp., 546 A.2d 452, 454-56 (Me. 1988) (allowing liquidatcd damages because the amount did not shock the senses despite the lack of actual damages).

119. See Samuel A. Rca, Jr., Efficiency Implications of Penalties and Liquidated Damages, $13 \mathrm{~J}$. LEG. STUD. 147, 150 (1984).

120. REsta TEMENT SECOND, supra note $15, \S 356 \mathrm{cmt}$. b. Illustrations 3 and 4 to $\S 356$ provide:

3. A contracts to build a grandstand for B's race track for $\$ 1,000,000$ by a specified date and to pay $\$ 1,000$ a day for every day's delay in completing it. A delays completion for ten days. If $\$ 1,000$ is not unreasonable in the light of the anticipatcd loss and the actual loss to $B$ 
It needs to be emphasized that the dynamic, second-look approach to the liquidated damages principle allows wide scope to liquidated damages provisions. Under that approach, a liquidated damages provision should relieve the plaintiff of the burden of proving damages, by shifting to the defendant the burden of establishing that the liquidated damages are disproportionate to the actual loss. ${ }^{121}$ Furthermore, a liquidated damages provision should allow the plaintiff to recover actual losses that would not otherwise be compensable because the legal rules governing contract damages do not provide full compensation. For example, a liquidated damages provision should be enforceable if it covers nonpecuniary losses, losses that would otherwise be too uncertain, litigation expenses, or losses whose recovery would otherwise be barred by the principle of Hadley $v$. Baxendale. Moreover, a liquidated damages provision should be enforced if the actual loss is determinable only within a wide range and the amount fixed by the provision is within that range. Finally, a liquidated damages provision should be enforceable even if the amount fixed is deliberately disproportionate to the expected loss, as long as it is clear that this is exactly what the parties have knowingly bargained for.

\section{E. The Excuse of Express Conditions}

Just as contract law has adopted a principle of special scrutiny of liquidated damages provisions, so too has it adopted a principle of special scrutiny of express conditions. A promise involves a commitment by a party that some specified state of events will or will not occur. An express condition qualifies a contractual duty by providing either that a party is not obliged to perform the duty unless a specified event occurs or fails to occur, or that the duty will be suspended or terminated if a specified event occurs or fails to occur. Thus, an express condition does not itself mvolve a commitinent, unless it is doing double duty as both an express condition and a promise. ${ }^{122}$

Promises and express conditions have very different consequences. If $A$ breaks an enforceable promise to $B, B$ always can recover damages, but nornially cannot terminate the contract unless the breach was material. In contrast, if $A$ fails to perfectly fulfill a condition to $B$ 's obligation to

is difficult to prove, A's promise is not a term providing for a penalty and its enforcement is not precluded....

4. The facts being otherwise as stated in Illustration 3, B is delayed for a month in obtaining permission to operate his race track so that it is certain that A's delay of ten days caused him no loss at all. Since the actual loss to B is not difficult to prove, A's promise is a term providing for a penalty and is unenforceable ....

Id. cmt. b, illus. 3-4.

121. See James Patrick Fenton, Note, Liquidated Damages as Prima Facie Evidence, 51 IND. L.J. $189,197-207$ (1975) (arguing that when breach has been shown but damages are difficult to ascertain, a rebuttable presumption should arise that the predetermined amount of liquidated damages is correct).

122. In some cases, however, a court may infer a promise from a condition. 
perform, then at least in principle $B$ can terminate the contract even if the failure is insignificant. Termination for nonfulfillment of an express condition is often a severe sanction, because $A$ may lose not only the value of the contract, but the value of his prior performance, subject to possible recovery for any benefit conferred.

Under classical contract law, conditions were governed by a static principle: the strict rule that express conditions as written must be perfectly fulfilled. Modern contract law has introduced a dynamic qualification, codified as follows in Restatement Second section 229: "To the extent that the non-occurrence of a condition would cause disproportionate forfeiture, a court may excuse the non-occurrence of that condition unless its occurrence was a material part of the agreed exchange." ${ }^{23}$ The comment to section 229 defines "forfeiture" as "the denial of compensation that results when the obligee loses his right to the agreed exchange after he has relied substantially, as by preparation or performance on the expectation of that exchange." ${ }^{24}$ The comment also makes clear that application of the principle embodied in section 229 depends on the actual result of enforcing a condition, rather than on the events at the time of contract formation:

Although both this Section and $\S 208$, on unconscionable contract or term, limit freedom of contract, they are designed to reach different types of situations. While $\S 208$ speaks of unconscionability "at the time the contract is made," this Section is concerned with forfeiture that would actually result if the condition were not excused. It is intended to deal with a term that does not appear to be unconscionable at the time the contract is made but that would, because of ensuing events, cause forfeiture. ${ }^{125}$

Accordingly, the modern principle that governs the excuse of conditions is explicitly based on a dynamic, second-look approach.

The cases amply support this principle. For example, in Hegeberg $v$. New England Fish Co., ${ }^{126}$ the Washington Supreme Court held that an insignificant departure from a time condition did not excuse nonperformance. The court noted that it had "not hesitated to grant relief from express conditions in contracts, where great injustice and undue hardship would

123. RESTATEMENT SECOND, supra note $17, \S 229$. Under a corollary principle expressed in $\S$ 227 (1), the courts put a thumb on the scales by favoring the interpretation of a contractual term as a promise if interpreting the term as a condition will increase the risk of forfeiture. See id. $\$ 227(1) \mathrm{cmt}$. b.

124. Id. $\$ 229 \mathrm{cmt}$. b. The comment continues:

In determining whether the forfeiture is "disproportionate," a court must wcigh the extent of the forfeiture by the obligee against the importance to the obligor of the risk from which he sought to be protccted and the degree to which that protection will be lost if the non-occurrence of the condition is excused to the extent required to prevent forfeiture.

Id.

125. Id.

126. 110 P.2d 182, 189 (Wash. 1941). 
result from strict enforcement of the terms of the agreement."127 In Holiday Inns of America, Inc. v. Knight, ${ }^{128}$ the California Supreme Court also granted relief from the operation of a time condition. $B$ had entered into an option contract with $S$ for the purchase of property that $B$ occupied as a tenant. The contract provided for an initial payment of $\$ 10,000$ and for four additional payments of $\$ 10,000$ on July 1 of each year thereafter. Under the contract, failure to make a payment on or before the specified date resulted in cancellation of the option. $B$ made timely payments in years 1 and 2 , and also made expenditures that substantially increased the value of the optioned property. In year 3 , however, $S$ did not receive $B$ 's check until July 2 , one day late. $S$ returned the check, stating that the option was canceled. ${ }^{129}$ The court refused to enforce the cancellation provision: "[T]he question is not whether the exercise of the option was timely, but whether the right to exercise the option in the future was forfeited by a failure to pay the consideration for that right precisely on time." 130

The principle that governs the excuse of express conditions, like the principle that governs the review of liquidated damages provisions, is best explained and justified by the limits of cogmition. Were it not for the limits of cognition, the law should no sooner excuse an express condition than it should refuse to enforce performance terms that turn out to be extremely disadvantageous to one party. However, the limits of cognition operate with respect to express conditions in a manner that closely parallels the operation of those limits with respect to liquidated damages provisions.

First, bounded rationality will often limit one or both parties' full comprehension of express conditions. The costs of determining the various ways in which an express condition may fail to be fulfilled are very high, because at the time of contracting a party cannot efficiently conceive every contingency under which nonfulfillment may occur. Indeed, not every contingency may be effectively conceivable at the time of contracting. Moreover, the benefits of incurring these costs are likely to seem dubious to a party on the verge of making a contract. Just as a liquidated damages provision bites only if a party fails to perform a promise, so an express condition bites only if it is not fulfilled. Because parties normally expect to fulfill conditions, the consequences of nonfulfillment often will seem remote at the time the contract is made. Accordingly, a contracting party is likely to view the costs of fully deliberating on the operation of an express condition as unduly high in light of the low probability that the condition will come into play. It is true that some contracting parties may give more

127. Id. at 188 .

128. 450 P.2d 42 (Cal. 1969).

129. See id. at 43.

130. Id. at 44. For similar treatment of express conditions, see, for example, Elliott v. Snyder, 143 S.E. $2 d$ 374, 375 (S.C. 1965) (refusing to allow a contract to be terminated despite a late installment payment). 
deliberation to an express condition than to a liquidated-damages provision, insofar as the operation of an express condition may be more specific. On the other hand, other contracting parties may give express conditions even less deliberation than liquidated damages provisions, because they may be unaware of the potentially draconian legal sanctions for insignificant variations from perfect fulfillment. Indeed, most parties may not even be aware of the legal distinction between promises and express conditions, or of the consequences of that distinction, which often present extremely difficult questions even for courts. ${ }^{131}$

The problem of irrationally optimistic disposition also has a special impact on express conditions. Because actors are unduly optimistic, a contracting party is likely to believe that fulfillment of an express condition is more likely, and nonfulfillment less likely, than is actually the case.

Finally, defects in capability will discourage parties from thinking through the consequences of express conditions. The availability heuristic is likely to lead a contracting party to give undue weight to his present intention to fulfill an express condition, which is vivid and concrete, as compared to the possibility that future circumstances inay lead to nonfulfillment, which is pallid and abstract. Moreover, the tendency to underestimate risks will likely cause a contracting party to underestimate the risk that an express condition will not be fulfilled.

As with liquidated-damages provisions, the cases illustrate how express conditions are vulnerable to the limits of cognition. In many cases, it seems clear that one or both parties failed to think through how a condition would operate. For example, in Jacob \& Youngs, Inc. v. Kent, ${ }^{132}$ plaintiff agreed to build a country residence for defendant. One of the plumbing specifications provided that "[a]ll wrought iron pipe inust be ... of the grade known as 'standard pipe' of Reading inanufacture."133 Final payment was conditioned upon a certificate of completion by the defendant's architect. Some of the pipe that plaintiff used was inade by Cohoes, rather than by Reading, and defendant's architect refused to give plaintiff a certificate of coinpletion. Plaintiff sued for the final payment. ${ }^{134}$ The difference in value between Reading and Cohoes pipe was "either nominal or

131. See, e.g., Brown-Marx Assocs., Ltd. v. Emigrant Sav. Bank, 703 F.2d 1361 (11th Cir. 1983) (concluding that a provision in a contract was a condition, not a promise, and that substantial performance was therefore insufficient to satisfy the provision); In re Carter's Claim, 134 A.2d 908 (Pa. 1957) (concluding that a provision in a contract was a condition, not a warranty, and that failure to fulfill the provision therefore did not give rise to an action for damages).

132. 129 N.E. 889 (N.Y. 1921).

133. Id. at 890 .

134. See id; see also Richard Danzig, The Capability Problem in Contract Law: Further READINGS ON WELL-KNOWN CASES, 108-12 (1978) (excerpting the actual contract at issue in Jacob \& Youngs); E.A. Farnsworth \& W. Young, Contracts-Cases and Materials 502 n.a (4th ed. 1988) (same). 
nothing." ${ }^{135}$ A pipe wholesaler interviewed after the decision explained that during the relevant period, genuine wrought-iron pipe was exclusively unanufactured by only four companies, including Reading and Cohoes. Each company produced pipe of absolutely identical quality and price. ${ }^{136}$ Builders and owners who wanted wrought iron pipe nauned pipe from one of the four manufacturers in their contracts. However, this practice was apparently not intended to distinguish among the four manufacturers, but simply to ensure that a contractor would not pass off, as wrought-iron pipe, imitation pipe produced by a manufacturer other than those four. ${ }^{137}$ Based on these facts, it seems highly unlikely that if the parties in Jacobs \& Young had thought the matter through, they would have agreed that all remaining payments due to the contractor could be withheld if the contractor installed pipe made by Cohoes that was identical to Reading pipe. Similarly, it seems highly unlikely that if the parties in Holiday Inn had thought the matter through, they would have agreed that if the optionee missed a payment by one day he would lose the value of all the payments and improvements he had made prior to that time. ${ }^{138}$

It might be argued that even if one contracting party, $A$, would be reluctant to agree to a condition if he fully understood that he would face draconian sanctions for insigmificant variations from perfect fulfillment, the other party, $B$, would insist on those sanctions. That is possible, but unlikely. If both parties fully understand that $B$ would have a right to terminate the contract if $A$ failed to fulfill a condition perfectly, no matter how trivial the failure, then the price to $B$ will be less advantageous than it otherwise would be, to compensate $A$ for his risk of termination in such a case. In cases like Jacobs \& Young and Holiday Inn, given perfect knowledge by both parties, $B$ would probably prefer to get a better price and forgo the power to impose draconian sanctions for less-than-perfect fulfillment of the condition, than to forgo the better price and retain that power.

Because the principle that governs the excuse of express conditions is best explained and justified by the limits of cognition, the contours of that principle should parallel the contours of the liquidated damages principle: If, in the nonfulfillinent scenario that actually occurred, allowing $B$ to terminate the contract on the ground that a condition was not perfectly fulfilled would result in a substantial loss to $A$ that is significantly out of proportion to $B$ 's interest in perfect fulfillment, termination should not be

135. Jacob \& Youngs, 129 N.E. at 891.

136. See DANZ1G, supra note 134, at 121 (quoting an unnamed pipe wholesaler).

137. See id. at 122. Trade bulletins of the period warned that some manufacturers of cheaper pipe sold their products under misleading names such as "wrought pipe." Even pipe labeled as "genuine wrought iron pipe" could contain steel scrap, one bulletin warned; it advised buyers to specify the name of a manufacturer known not to use scrap. See id.

138. See supra text accompanying notes $128-130$. 
permitted unless it is established that the parties had a specific and wellthought-through intention that termination could be effected in a scenario like the one that actually occurred.

\section{F. Offer and Acceptance; the Duty to Negotiate in Good Faith}

\section{Classical contract law}

One of the axioms of classical contract law was that a contract is formed by offer and acceptance. This axiom was at the center of several clusters of offer-and-acceptance rules. One of these clusters purported to be based on deduction from the bargain theory of consideration. Within this cluster was the rule that a firm offer could be revoked. Another cluster purported to be based on interpretive concepts. Within this cluster was the rule that a counter-offer terminates the power of acceptance. In this Part, I will focus on a third cluster of rules, which concern preliminary negotiations, indefiniteness, further-document-to-follow provisions, gaps, agreements to agree, and the duty to negotiate in good faith.

\section{a. Preliminary negotiations}

One set of rules within this cluster concerned the characterization and effect of expressions used in a bargaining context. Under classical contract law, such expressions were characterized as either an offer or acceptance on the one hand, or as preliminary negotiations on the other. This was a binary characterization, in which an expression either had immediate legal effect, or no legal effect. An offer had the immediate legal effect of creating a power of acceptance in the offeree and an acceptance had the immediate legal effect of concluding a contract. Preliminary negotiations had no legal effect. This binary characterization was reflected in binary outcomes: no liability up to the time at which an acceptance of an offer occurred; full liability for expectation damages thereafter.

\section{b. Indefiniteness}

Another set of rules in this cluster concerned the indefiniteness of agreements. The relationship between the basic rules of offer and acceptance and the rules concerning indefiniteness was not always clear. A basic rule of offer and acceptance is that an expression will not constitute an offer unless it is sufficiently definite. But why then should contract law have another rule about the indefiniteness of agreements? If an expression is not sufficiently definite to constitute an offer, no contract can be formed. If an expression is sufficiently defmite to constitute an offer, what room is left to argue that a resulting agreement is too indefinite?

One possible answer to this question is that the concept of indefiniteness reflects the brute fact that in reality most contracts are not formed by an offer-and-acceptance sequence. Instead, most contracts are probably 
formed by simultaneous actions, like sigming, shaking hands, concurring that "It's a deal," or the like. In such cases, whether one of the parties used an expression that was sufficiently defimite to constitute an offer is usually irrelevant. Instead, indefiniteness bears on whether parties to a joint expression that looks like an agreement did not believe that they had concluded the bargaining process, but rather believed only that they were still in preliminary negotiations-preliminary, that is, to the conclusion of a bargain. In addition, indefiniteness may be relevant because even if the parties believed they had concluded the bargaining process, the bargain they made may be too indefinite to allow the courts to fashion a remedy for its breach. The rules of classical contract law concerning indefiniteness tended to be static, because generally speaking the determination whether an agreement was sufficiently definite to be enforceable focused on the terms of the agreement at the time that it was made.

\section{c. Further-document-to-follow}

Still another set of rules in the offer-and-acceptance cluster involved fact patterns in which the parties had made an agreement that would look as if it were a completed bargain except for the fact that the parties included in the agreement a provision that contemplated a further document. I will refer to these kinds of provisions as further-document-to-follow provisions. Of course, if the agreement the parties made flunked the indefiniteness test even without regard to such a provision, the provision would have no added significance. Often, however, an agreement would be sufficiently definite but for the presence of such a provision. The question then is, what is the legal significance of the provision? The rule of classical contract law again was binary and static. If the parties intended the later document as only an evidentiary memorial of the terms of their agreement, and the agreement was otherwise complete, then the agreement was enforceable. If, however, the parties intended not to be bound unless and until the further document was executed, so that the further docunient was to be the consummation of their negotiations, then the agreement was unenforceable. Accordingly, either the parties' contemplation of a further document prevented the formation of a contract, in which case there was no liability, or it did not, in which case there was a contract on the terms of the agreement.

\section{d. Gaps}

Closely related to the indefimiteness and further-document-to follow problems was the issue how to treat "gaps" (including "omissions" or "open terms") in an agreement. The concept of gaps is confused, because it is unclear what the difference is, or indeed whether there is a difference, between the special problein of gaps, on the one hand, and the general 
problem of interpretation, on the other. After all, any case in which interpretation is required can be characterized as a case in which there is a gap in a contract: If a problem arises concerning how to treat a given issue under a contract, there is little or no functional difference between saying that the contract requires interpretation and saying that the contract has gaps. Similarly, there is little or no functional difference between saying that the contract requires no interpretation and saying that the contract has no gaps.

Be that as it may, under classical contract law gaps were treated in a binary, static fashion, just like the other issues considered in this section. Either a gap did not prevent an agreement from constituting a sufficiently definite contract, in which case the court would fill the gap (or stand ready to fill the gap) and enforce the agreement, or the gap prevented the agreement from being sufficiently definite, in which case the court would hold the agreement to be unenforceable.

\section{e. Agreements to agree and the duty to negotiate in good faith}

Classical contract law did not recognize a duty to negotiate in good faith. On the contrary, it adopted the rule that an agreement to agree was unenforceable, which by implication precluded an obligation to negotiate in good faith. The most famous statement of this rule was that of Lord Wensleydale in Ridgeway $v$. Wharton: ${ }^{139}$

An agreement to be finally settled must comprise all the terms which the parties intend to introduce into the agreement. An agreement to enter into an agreement upon terms to be afterwards settled between the parties is a contradiction in terms. It is absurd to say that a man enters into an agreement till the terms of that agreement are settled. Until those terms are settled he is perfectly at liberty to retire from the bargain. ${ }^{140}$

\section{Modern contract law}

Modern contract law has made a number of dynamic departures from the static offer-and-acceptance model of classical contract law. Among these departures are rules that recognize that the formation of a contract may be a dynamic, evolving process, rather than a process that can be located at a fixed moment in time. For example, Uniform Commercial Code section 2-204(1) provides that "A contract for the sale of goods may be made in any manner sufficient to show agreement, including conduct by both parties which recognizes the existence of such a contract." ${ }^{141}$ Even more explicitly, section 2-204(2) provides that "An agreement sufficient to constitute a contract for sale may be found even though the moment of

139. 10 Eng. Rep. 1287 (H.L. 1857).

140. Id. at 1313 .

141. U.C.C. \& 2-204(1). 
making it is undetermined."142 Similarly, the Restatement Second section 22(1) provides that "A manifestation of mutual assent may be made even though neither offer nor acceptance can be identified and even though the moment of contract formation cannot be determined."143

An even more important development in the transformation of offerand-acceptance law has been the acceptance in modern contract law of the dynamic rule that there is an obligation under appropriate circumstances to negotiate in good faith. The adoption of this rule is important not only in itself, but also because it provides a foundation for the dynamic treatment of preliminary negotiations, indefiniteness, further-document-to-follow provisions, and gaps.

I will begin by addressing the duty to negotiate in good faith as it arises in three kinds of cases, in ascending order of difficulty: (i) Cases involving an explicit agreement concerning the conduct of negotiations; (ii) Cases in which there is an implicit agreement to negotiate in good faith; (iii) Cases in which a party's conduct results in the imposition of a duty to negotiate in good faith.

\section{a. Cases involving an explicit agreement concerning the conduct of negotiations}

Cases involving an explicit promise concerning the conduct of negotiations fall into two general categories-promises about how the parties will negotiate, such as a promise to negotiate in good faith, and promises not to negotiate with others during a designated period of time, sometimes referred to as lock-out agreements.

A leading case in the first category is Itek Corp v. Chicago Aerial Industries, Inc. ${ }^{144}$ In spring 1964, Itek became interested in the acquisition of CAI's assets. Approximately fifty percent of CAI's stock was owned by its president and the estates of two of CAI's founders. Negotiations reached a climax in autumn 1964, when CAI conditionally accepted an offer by Itek to purchase CAI's assets for a price equal to thirteen dollars per share. The principal CAI shareholders agreed, and CAI's board agreed to recommend acceptance of Itek's offer to the remaining shareholders. On January 4, 1965, CAI told Itek of this agreement, subject to the conditions that Itek obtain the necessary financing, that an informal letter of intent be executed, that the details be worked out, and that formal documents be prepared to the satisfaction of the parties.

Subsequently, Itek arranged the financing, and on January 15, 1965, the following letter, on Itek letterhead, was signed by both parties:

142. U.C.C. \$ 2-204(2).

143. RESTATEMENT SECOND, supra note 17, § 22(1).

144. 248 A.2d 625 (Del. 1968). 
Chicago Aerial Industries, Inc.

550 West Northwest Highway

Barrington, Illinois

Gentlemen:

This is to confirm the terms on which Itek Corporation (Itek) and Chicago Aerial Industries, Inc. (CAI) have agreed, with the approval of their respective Boards of Directors, to work towards a combination of the two companies through the purchase of the assets and assumption of specified liabilities of CAI by ltek, all subject to adoption of a plan of liquidation and approval of such sale by CAI stockholders:

1. The purchase price to be paid by Itek for all of the assets of CAI (including name and goodwill), subject to the liabilities to be assumed by Itek, is $\$ 6,759,600$ in cash plus 28,165 shares of ltek common stock, par value $\$ 1.00$ per share, subject to proportionate increase for outstanding CAI stock options exercised after December 31, 1964. The liabilities of CAI to be assumed by ltek are only those which shall be shown in CAI's balance sheet as of December 31,1964, together with any liabilities incurred in the ordinary course of business after that date and such other liabilities of CAI as the parties may agree upon.

2. Itek and CAI shall make every reasonable effort to agree upon and have prepared as quickly as possible a contract providing for the foregoing purchase by Itek and sale by CAI, subject to the approval of CAI Stockholders, embodying the above terms and such other terms and conditions as the parties shall agree upon. If the parties fail to agree upon and execute such a contract they shall be under no further obligation to one another.

If you agree to the foregoing please so indicate by signing and returning the enclosed copy of this letter.

Yours very truly,

ITEK CORPORATION

By Edwin D. Campbell

Executive Vice President

AGREED:

CHICAGO AERIAL INDUSTRIES, INC.

By Fred T. Sonne-President ${ }^{145}$

145. 248 A.2d at $627-28$. 
CAI and Itek then began the preparation of a formal agreement. Meanwhile, in early February, CAI and its principal shareholders had entered into secret negotiations with Bourns, Inc. for the sale of CAI's stock. On February 15, Bourns outlined an offer under which it would purchase the largest shareholders' CAI stock for $\$ 16$ per share. In late February, CAI's principal stockholders agreed to sell their CAI stock to Bourns at that price. CAI then notified Itek that it was terminating the Itek transaction as a result of unforeseen circumstances and the failure of the parties to reach agreement.

Itek then sued CAI for breach of contract. The trial court granted summary judgment for CAI because of the sentence in the letter agreement that if the parties failed to agree upon and execute a formal contract they would be under no further obligation. The Delaware Supreme Court reversed:

[T]t is apparent that the parties obligated themselves to "make every reasonable effort" to agree upon a formal contract, and only if such effort failed were they absolved from "further obligation" for having "failed" to agree upon and execute a formal contract. We think these provisions of the January 15 letter obligated each side to attempt in good faith to reach final and formal agreement.

... There is ... evidence which, if accepted by the trier of fact would support the conclusion that subsequently, in order to permit it's stockholders to accept a higher offer, CAI willfully failed to negotiate in good faith and to make "every reasonable effort" to agree upon a formal contract, as it was required to do. ${ }^{146}$

In Itek, the parties agreed to make "every reasonable effort to agree upon ... a contract." ${ }^{\prime 47}$ A counterpart case is that in which a negotiating party promises not to negotiate with third parties. For example, in Channel Home Centers v. Grossman, ${ }^{148}$ Frank Grossman, a real estate broker and developer, was in the process of acquiring ownership of Cedarbrook Mall. ${ }^{149}$ The Mall had fallen on hard times, and Grossman intended to revitalize it through an aggressive rehabilitation and leasing program. Channel Home Centers, a division of Grace Retail Corporation, operated home-improvement stores. In late November 1984, Grossman informed Channel of the availability of a store location in Cedarbrook Mall. Channel indicated that it wanted to lease the site. Grossman then requested that Channel execute a letter of intent that, as Grossman put it, could be shown

146. Id. at 629 .

147. Id. at 627 .

148. 795 F.2d 291 (3d Cir. 1986).

149. For ease of exposition, I use "Grossman" as shorthand for Frank Grossman, his sons, and a corporation they controlled. 
to "other people, banks, or whatever."150 Apparently, Grossman was anxious to get Channel's signature on a letter of intent that could be used to help secure financing for his purchase of the mall. In response to Grossman's request, Channel prepared, executed, and submitted a detailed letter of intent setting forth a great number of highly specific lease terms. The letter of intent specified that execution of the lease was expressly subject to Grace's approval of the essential business terms of the lease; to Channel's approval of the status of title for the site; and to Channel's obtaining, with Frank Grossman's cooperation, all necessary permits and zoning variances for the erection of Channel's identification signs. The letter also stated that:

To induce the Tenant [Channel] to proceed with the leasing of this Store, you [Grossman] will withdraw the Store from the rental market, and only negotiate the above described leasing transaction to completion.

Please acknowledge your intent to proceed with the leasing of the store under the above terms, conditions and understanding by signing the enclosed copy of the letter and returning it to the undersigned within ten (10) days from the date hereof. ${ }^{151}$

Frank Grossman promptly signed the letter of intent and returned it to Channel. Thereafter, both parties initiated procedures directed toward satisfaction of lease contingencies, and on January 11 Grace's legal department sent Frank Grossman a forty-one-page draft lease. Shortly thereafter, a major competitor of Channel, Mr. Good Buys, contacted Frank Grossman and stated that it would be interested in leasing space at Cedarbrook Mall. Mr. Good Buys agreed to make base-level annual rental payments that were substantially greater than those agreed to by Channel in the letter of intent. On February 6, Frank Grossman notified Channel that "negotiations [are] terminated as of this date."152

The trial court concluded that the letter of intent did not bind the parties to any obligation, and was unenforceable for lack of consideration. The Third Circuit reversed:

It is hornbook law that evidence of preliminary negotiations or an agreement to enter into a binding contract in the future does not alone constitute a contract. Appellees believe that this doctrine settles this case, but in so arguing, appellees misconstrue Channel's contract claim. Channel does not contend that the letter of intent is binding as a lease or an agreement to enter into a lease. Rather, it is Channel's position that this document is enforceable as a mutually binding obligation to negotiate in good faith. By unilaterally

150. 795 F.2d at 291 .

151. Id. at 293.

152. Id. at 296 . 
terminating negotiations with Channel and precipitously entering into a lease agreement with $\mathrm{Mr}$. Good Buys, Channel argues, Grossman acted in bad faith and breached his promise to "withdraw the Store from the rental market and only negotiate the above-described leasing transaction to completion"

... The letter of intent, signed by both parties, provides that " $[t]$ o induce the Tenant [Channel] to proceed with the leasing of the Store, you [Grossman] will withdraw the Store from the rental market, and only negotiate the above described leasing transaction to completion." The agreement thus contains an unequivocal promise by Grossman to withdraw the store from the rental market and to negotiate the proposed leasing transaction with Channel to completion.

Evidence of record supports the proposition that the parties intended this promise to be binding. ... Accordingly, the letter of intent and the circumstances surrounding its adoption both support a finding that the parties intended to be bound by an agreement to negotiate in good faith. ${ }^{153}$

Viewed in light of the basic principles of contract law, Itek and Channel Home are in some sense unremarkable cases. In each case, a party made a promise and broke it. In each case, the promise had consideration. In Itek, the parties made a bargain (in the form of a conventional bilateral contract) to use every reasonable effort to agree upon a final contract. In Channel Home, Channel Home supplied a commitment letter that Grossman needed to get financing, so that there was a bargam (in the form of a unilateral contract) in which Channel Home's commitment letter was exchanged for Grossman's promise not to negotiate with third parties and instead to negotiate the transaction with Channel to completion.

What then is significant about cases like Itek and Channel Home? First, they essentially reverse the classical rule concerning agreements to agree. Second, they explicitly speak of an obligation to negotiate in good faith. In Itek the court said that "the provisions of the [letter of intent] obligated each side to attempt in good faith to reach final and formal agreement." 154 In Channel Home the court said that "the letter of intent and the circumstances surrounding its adoption both support a finding that the parties intended to be bound by an agreement to negotiate in good faith."15s

Why did the courts in these cases speak of a duty to negotiate in good faith, rather than simply repeating or paraphrasing the literal promises, to "make every reasonable effort to agree upon . . . a contract," in Itek, and to

153. Id. at 298-300 (citations and footnotes omitted).

154. 1tek Corp. v. Chicago Aerial lndus., Inc., 248 A.2d 625, 629 (Del. 1968).

155. 795 F.2d at 299-300. 
"withdraw the Store from the rental market, and...negotiate the ... leasing transaction to completion," in Channel Home? There are two possible, not inconsistent explanations. One explanation is that the courts were simply applying the well-established rule that a contract obligation must be performed in good faith. Where the required performance consists of negotiation, then the negotiation must be in good faith. ${ }^{156}$ Under this explanation, the courts were simply pointing out a consequence of a contractual duty to negotiate. The second explanation is that when a party is under an obligation to negotiate, the only way to make sense out of that obligation is to require that the party negotiate in good faith.

\section{b. Cases in which there is an implicit agreement to negotiate in good faith}

Cases like Itek and Channel Home are extremely important in helping to establish the duty to negotiate in good faith, but the analysis in those cases is not extensive, and both cases involved explicit agreements concerning the conduct of negotiations. In contrast, in Teachers Insurance and Annuity Association of America v. Tribune Co., ${ }^{157}$ Judge Pierre Leval developed an extensive and masterful analysis of the duty to negotiate in good faith in the context of an implicit agreement to negotiate in good faith. Although the case concerned a commitment letter, it laid a foundation for a reanalysis of the entire cluster of offer-and-acceptance rules considered in this Part.

To raise cash that it needed for a number of purposes, including the operation of its newspaper, The New York Daily News, Tribune Company decided to sell the News Building. To this end, Tribune entered negotiations to sell the Building to LaSalle Partners as part of a complex threeparty transaction. The concept of the transaction was as follows: LaSalle would pay for the News Building by giving Tribune a mortgage note secured by a mortgage. Accordingly, the LaSalle transaction, taken in itself, would produce no immediate cash for Tribune. However, Tribune would "match fund" the note by borrowing from a lending institution an amount of money equal to the mortgage note. The loan agreement with the lending institution would provide that Tribune could pay off its own note to the institution by "putting" (delivering to the institution), in place of its own note, the mortgage note that Tribune would receive from LaSalle. To compensate the lender for the additional risk inherent in the possible put, Tribune would pay the lender a premium above market interest rates.

The complex nature of the proposed transaction was largely driven by tax motives, but there was also an accounting element to the transaction.

156. See, e.g., LLMD v. Marine Midland Realty Credit Corp., 789 F.Supp. 657, 660 (E.D. Pa. 1992).

157. 670 F. Supp. 491 (S.D.N.Y. 1987). 
Tribune believed that because it would have the right to put the mortgage note to the lending institution in full satisfaction of its debt, it would not be required to include its debt to the lending institution as a liability on its balance sheet. Instead, Tribune believed, it could employ offset accounting, under which it would set off its debt to the lending institution against the mortgage note, eliminate both its debt and the mortgage note from its balance sheet, and instead describe the debt and mortgage note in the footnotes to its financial statements.

For tax reasons, it was important that the transaction be completed during 1982. Tribune prepared a list of six institutions, including Teachers Insurance and Annuity Association of America ("Teachers" or "TIAA"), that it believed would have the means and flexibility to make a loan with these specifications. All but Teachers promptly rejected the deal. On August 20, Scott Smith, Tribune's Vice President and Treasurer, sent Martha Driver, of Teachers, an Offering Circular, including a term sheet, describing the proposed transaction. Smith's letter stated, "While we are flexible on funds delivery, our objective is to have a firm commitment from a lender by September 15, 1982. Consequently, we need to move the due diligence and negotiation process along very quickly." 158 On September 16, Teachers' Finance Committee met and approved the Tribune loan. Driver then told Smith that Teachers would promptly issue its commitment letter.

The commitment letter, mailed on September 22, included a two-page Summary of Proposed Terms, drawn from Tribune's term sheet and ensuing conversations. Teachers' term sheet covered all the basic economic terms of a loan. Neither the term sheet nor the commitment letter made reference to offset accounting. The letter stated that the agreement was "contingent upon the preparation, execution and delivery of documents ... in form and substance satisfactory to TIAA and to TIAA's special counsel," 159 and that the transaction documents would contain the usual and customary representations and warranties, closing conditions, other covenants, and events of default "as we and our special counsel may deem reasonably necessary to accomplish this transaction." 160 The letter concluded by inviting Tribune to "evidence acceptance of the conditions of this letter by having it executed below by a duly authorized officer,"161 and added that "Upon receipt by TIAA of an accepted counterpart of this letter, our agreement to purchase from you and your agreement to issue sell

158. Id.

159. Id. at 494 .

160. Id.

161. Id. 
and deliver to us ... the captioned securities, shall become a binding agreement between us." 162

The "binding agreement" language in the commitment letter caused serious concern to Tribune's lawyers. Tribune's outside counsel advised Smith not to sign a letter containing binding agreement language. ${ }^{163} \mathrm{But}$ having been turned down by five other institutions, Smith did not want to risk losing Teachers' commitment. Therefore, he did not question the "binding agreement" language. Instead, he executed the commitment letter on Tribune's behalf, and added a notation that the commitment letter was subject to certain modifications outlined in his covering letter. ln the covering letter, Smith wrote that "[O]ur acceptance and agreement is subject to approval by the Company's Board of Directors and the preparation and execution of legal documentation satisfactory to the Company." 164 The covering letter, like the commitment letter, made no mention of offset accounting.

On October 28, Tribune's board resolved "that the proper officers of the Company be and they hereby are authorized" to effect the borrowing "with all of the actual terms and conditions to be subject to the prior approval by resolution of the Finance Committee."165 In the meantime, however, interest rates had dropped rapidly, and were now substantially below the rates that prevailed when Teachers and Tribune had entered into the commitment letter. In addition, Tribune began to be concerned that its accountants would not approve Tribune's use of offset accounting for the transaction.

On December 6, Tribune and Lasalle closed the sale of the building. Teachers became concerned that Tribune, which could now borrow at substantially lower rates, was seeking to back out of the transaction, and pressed Tribune to put the loan documents into final form. Teachers dropped a demand it had made for conditions on Tribune's exercise of the put. It asked for a meeting to iron out all open issues. But the fall in interest rates, together with doubts as to the availability of offset accounting, now made the deal much less attractive to Tribune. Smith therefore replied that there was no point in meeting unless Teachers was willing to agree that Tribune's obligation to close the Teachers loan would be conditional on Tribune's ability to use offset accounting. Teachers responded that Tribune's accounting was not part of the deal. When Tribune exhibited no further interest in pursuing the transaction, Teachers brought suit.

162. Id.

163. A few days before Tribune had entered into a letter of intent with LaSalle for the sale of the building which, in contrast, expressly provided that it was "not a binding agreement." Id. at 494, n.1.

164. Id.

165. Id. at 495 . 
To decide the case, Judge Leval created a tripartite classification of preliminary agreements. The first category consists of preliminary agreeinents that create no binding legal obligation. The second category consists of agreements that are "preliminary only in form-only in the sense that the parties desire a more elaborate formalization of the agreement."166 Judge Leval called these agreements preliminary contracts. A preliminary contract occurs when the parties have reached complete agreement, including agreement to be bound, on all the issues perceived to require negotiation. Such an agreement is not the first stage of an ongoing negotiation. Instead, it is a final agreement, so that the document to follow is simply a formalization of an agreement that has already been reached. In such cases, execution of a later document is not necessary, but merely considered desirable. Therefore, the fact that the parties contemplate memorializing their agreement in a more formal document does not prevent their agreement from immediately taking effect.

The third category of preliminary agreements consists of agreements that express a mutual commitment to a contract on agreed major terms, while recognizing the existence of open terms that need to be negotiated. Of course, the existence of open terms may suggest that a binding agreement has not been reached, but that is not necessarily so. The parties, Judge Leval said, "can bind themselves to a concededly incomplete agreement in the sense that they accept a mutual commitment to negotiate in good faith in an effort to reach final agreement within the scope that has been settled in the preliminary agreement." 167 Judge Leval called such agreements binding preliminary agreements. ${ }^{168} \mathrm{~A}$ preliminary contract binds both sides "to their ultimate contractual objective," in recognition that a contract has been reached despite the anticipation of further formalities. In contrast, a binding preliminary agreement "does not commit the parties to their ultimate contractual objective, but rather to the obligation to negotiate the open issues in good faith in an attempt to reach the alternate objective withm the agreed framework." 169 Accordingly, in the case of a preliminary contract, a party has a legal right to demand performance of the agreement even if no further steps have been taken following the making of the contract. In contrast, in the case of a binding preliminary agreement, a party does not have a legal right to demand performance. What he may demand is that his counterparty negotiate the open terms in good faith toward a final contract incorporating the agreed terms: ${ }^{170}$

166. Id.

167. Id. at 498 .

168. Id.

169. Id.

170. See id. 
This obligation does not guarantee that the final contract will be concluded if both parties comport with their obligation, as good faith differences in the negotiation of the open issues may prevent a reaching of final contract.... The obligation does, however, bar a party from renouncing the deal, abandoning the negotiations, or insisting on conditions that do not conform to the preliminary agreement. ${ }^{171}$

Applying this tripartite legal regime to the facts of Tribune, Judge Leval concluded that the Tribune-Teachers commitment letter represented a binding preliminary agreement, which obliged both parties to seek to conclude a final loan agreement upon the agreed terms, by negotiating in good faith to resolve such additional terms as are customary in such agreements. In reaching this conclusion, Judge Leval pointed out that the exchange of letters was replete with the terminology of a binding contract, such as "please evidence acceptance of the conditions of this letter by having it executed below by a duly authorized officer"172; and "[u]pon receipt by [Teachers] of an accepted counterpart of this letter, our agreement to purchase from you and your agreement to issue, sell and deliver to us ... the captioned securities, shall become a binding agreement between us" surrounding circumstances also showed that a binding commitment was precisely what Tribune wanted.

[Tribune's proposal letter advised Teachers that] Tribune wanted to have a "firm commitment from a lender by September 15, 1982." If such a "firm commitment" meant nothing more than Tribune now contends it does, such a commitment would have been of little value, as the lender would have remained free to abandon the loan if it decided at any time that the transaction did not suit its purposes, whether because of changed interest rates or for any reason: Tribune wanted a firm commitment because it felt it needed to be sure the transaction would be concluded by the end of the year. ${ }^{175}$

Finally, concerning Tribune's reservation that "our acceptance and agreement is subject to approval by the Company's Board of Directors and the preparation and execution of legal documentation satisfactory to the Company," ${ }^{\prime 76}$ and similar reservations on Teachers' side, Judge Leval held that such terms are not incompatible with intention to be bound:

\footnotetext{
171. Id.

172. Id.

173. Id at 499 .

174. Id.

175. Id. at 500 .

176. Id. at 494 .
} 
Since the parties recognize that their deal will involve further documentation and further negotiation of open terms, such reservations make clear the right of a party, or of its Board, to insist on appropriate documentation and to negotiate for or demand protections which are customary for such transactions ....

[T]he reservation of Board approval and the expressed "contingen[cy] upon the preparation, execution and delivery of documents" did not override and nullify the acknowledgment that a "binding agreement" had been made on the stated terms; those reservations merely recognized that various issues and documentation remained open which also would require negotiation and approval. If full consideration of the circumstances and the contract language indicates that there was a mutual intent to be bound to a preliminary commitment, the presence of such reservations does not free a party to walk away from its deal merely because it later decides that the deal is not in its interest .... ${ }^{177}$

Teachers would not have been free to walk away from the loan by reason of a subsequent decision that the transaction was not in Teachers' interest. Nor could Tribune. ${ }^{178}$

Tribune marks a significant jump forward from Itek and Channel Home for two reasons. First, unlike Itek and Channel Home, in Tribune the parties did not explicitly agree to negotiate in good faith, although they did use explicit language normally associated with a contract, such as "binding commitment." Second and more important is the analysis itself; in particular, the tripartite distinction between agreements that have no binding effect at all, agreements that bind the parties to render a designated performance, and agreements that bind the parties to negotiate in good faith to consummate a final agreement.

Before exploring the full significance of this analysis, I will deal with a possible objection to the duty to negotiate in good faith: that such a duty cannot be administered on a meaningful basis, because it cannot readily be determined whether a party failed to negotiate in good faith. Such an objection would not be well-taken. In most cases, there is no real doubt about this issue, because the defendant clearly shows bad faith by negotiating with third parties, as in Itek and Channel Home, or by breaking off negotiations with no good reason. ${ }^{179}$

Of course, it is possible that a well-schooled party might opportunistically go through the motions of bargaining in good faith while having no sincere desire to reach agreement. However, this risk is not a

177. Id. at 500 .

178. Id. at 500-01.

179. See, e.g., Arnold Palmer Gold Co. v. Fuqua Indus., Inc., 541 F.2d 584 (6th Cir. 1976). 
reason against recognizing the enforceability of an express or implied commitment to negotiate in good faith. The law should not take the position that a commitment to negotiate in good faith will be unenforceable against those who clearly act in bad faith just because some parties who act in bad faith will be able to escape liability. In any event, a party who is negotiating in bad faith typically leaves so many footprints that the determination that he negotiated in bad faith will be very easy. Moreover, going through the motions is often a difficult trick to pull off. To be successful, the opportunist will need to avoid probing the market for a better deal during the course of the negotiations, which may not be inviting. An opportunist may also have to show that he made a good faith counter-offer to the proposal to which he objected. This may not be easy: If the counteroffer is unreasonable, it will evidence bad faith. If the counter-offer is reasonable, it may be accepted. These points are exemplified in Teachers Insurance \& Annuity Association v. Butler ${ }^{180}$ OCCA, a limited partnership, undertook the development and construction of a high-rise office building in Sacramento. To get interim construction financing, OCCA needed a commitment for permanent financing. In September 1982, Teachers issued a commitment letter for permanent financing, which was accepted by OCCA. Under the letter, Teachers agreed to lend, and OCCA agreed to borrow, $\$ 20$ million for a thirty-five-year term at a fixed interest rate of $14.25 \%$, plus a kicker in the form of a contingent interest in rental returns over the life of the loan. Voluntary prepayment by OCCA was permitted only during the last eighteen years of the loan, and even then, only upon payment of a premium. ${ }^{181}$

In July 1983, Teachers' counsel sent proposed closing documents to OCCA for review and comment. One provision in these documents (the "default-fee provision") stated that if Teachers accelerated payment of the loan by reason of OCCA's default, a tender by OCCA of the entire indebtedness would be deemed to constitute a voluntary prepayment. ${ }^{182}$ Meanwhile, interest rates had dramatically declined, so that the loan had become much less attractive to OCCA. Just before the closing, OCCA notified Teachers that it was unwilling to accept the loan as long as the documents contained the default-fee provision. Teachers then brought suit to recover damages based on OCCA's failure to negotiate in good faith. OCCA's purported objection to the provision, Teachers claimed, was only a pretext for OCCA's unwillingness to proceed with the transaction as a result of the dramatic decline in interest rates. ${ }^{183}$

180. 626 F. Supp. 1229 (S.D.N.Y. 1986).

181. See id. at 1229-30.

182. See id. at 1230-31.

183. See id. 
OCCA conceded that the commitment letter was binding. However, it argued, the commitment letter made no provision for a default-fee provision, so that OCCA's refusal to accept the default-fee provision was not a failure to negotiate in good faith. The court disagreed, and held for Teachers, pointing to a variety of circumstances that made it clear that OCCA had not negotiated in good faith. For example, almost from the time OCCA had obligated itself under the commitment letter it began commumcating with various lenders and brokers to find a better loan. In effect, once OCCA had obtained the permanent-loan commitment necessary to begin construction, it took advantage of the nineteen-month period before the scheduled closing to seek a more favorable loan package from another lender. Furthermore, although OCCA knew sometime in February that the closing documents contained the default-fee provision, it made no objection to the provision until April 26, only four days before the closing. In addition, OCCA insisted that the default-fee provision be deleted in its entirety; it made no counter-offers with respect to the amount of a default fee, nor was it willing to negotiate the terms of such a fee. Fmally, the defaultfee provision requested by Teachers reflected the intent of the deal, and the inclusion of such clauses was the custom and practice in the Califorma real estate financing market. Indeed, mine months after rejecting Teachers' default prepayment fee, OCCA signed closing documents with Aetna that provided OCCA with more money at a lower interest rate and without a kicker, but included a default-fee provision. ${ }^{184}$

The great ease with which bad faith is shown in cases like Itek and Channel Home, and the relative ease with which it is shown in cases like Tribune and Butler, appear to be typical. Of course, it is possible that bad faith will be erroneously found where it does not exist in fact. That risk does not seem more serious than the risk of error in the application of many other legal principles. In any event, that risk can be dealt with by requiring a party who seeks to establish negotiation in bad faith to make a relatively clear showing.

A final issue raised by the enforcement of commitments to negotiate in good faith concerns the appropriate measure of damages. Where such a commitment is part of a bargain, the injured party should be awarded expectation damages. Of course the deal imght have broken down even if the other party had negotiated in good faith. However, because that party's wrongful acts made it impossible to determine what would have happened if she had acted in good faith, she should bear the burden of proving the deal would have broken down even if she had so acted. If expectation damages are too uncertain, the court should award reliance damages measured by out-of-pocket costs or, where appropriate, by lost opportunities.

184. Id. at 1234-35. 
I turn now to the broader implications of the Tribune tripartite legal regime. This regime differs from classical contract law in two critical respects. First, the regime of classical contract law concerning the issues considered in this section was binary: either a contract was fully enforceable as made or it was not enforceable at all. In contrast, the Tribune regime is multi-faceted, because it organizes the experience it concerns into several states, including an intermediate state between no liability and full hability.

Second, and more important, the regime of classical contract law concerning the issues considered in this section was by and large static. In contrast, the Tribune regime is dynamic, because its applicability will often depend on the course of negotiation after the relevant agreement has been made.

The dynamic aspect of the Tribune tripartite regime sweeps much further than the subject-matter of the Tribune case itself. The agreement before the court in Tribune was a relatively formal commitment letter. Such letters are not uncommon in important transactions, so that the Tribune regime would be important even if it was confined to agreements of this type. In fact, however, the implications of theTribune regime extend to the whole cluster of rules that have been considered in this Part, and radically shift the legal regime that governs all the problems covered by those rules.

To begin with, the Tribune tripartite legal regime is applicable to any further-document-to-follow provision. Such a provision may show that the parties had not reached a final contract, but the question will remain whether they had implicitly agreed to negotiate in good faith to reach such a contract. Often, the answer will be that the parties had made such an implicit agreement. That is especially likely to be true where the point of the further-document-to-follow provision was to turn the matter over to the parties' lawyers. When a deal is turned over by business persons to lawyers, the lawyers are expected to wrap up the deal, not to renegotiate the settled terms. Of course, it may turn out that the unsettled terms are dealbreakers, or that there are a range of reasonable provisions that will effectuate the settled terms, and the deal breaks down because of differences over where in the range a provision should be. Often too, the formalization process smokes out hidden problems. None of these possible barriers to reaching final agreement are inconsistent with an obligation to negotiate in good faith to reach such an agreement. In a further-document-to-follow case, the baseline of that obligation is that a party will not break the deal by trying to back out of a term he has agreed to, either directly by insisting on renegotiating the term, or indirectly by refusing to accept the fair implications of the term. 
The Tribune tripartite legal regime also applies to the issue of gaps. Gaps may be so large as to show that the parties had neither concluded a deal nor made an implicit agreement to negotiate in good faith. But if the parties have purported to conclude a deal, it will often be fair to imply that they are committed to negotiate in good faith to close those gaps in the deal that turn out to need resolution. As Judge Leval stated in Tribune:

[The existence of open points in the commitment letter] is of no consequence because they did not break the deal. Teachers offered in mid-December to sit down with Tribune and resolve all open issues so that the first drawdown could be made before the end of the year as contemplated in the commitment letter; Tribune declined stating that such a meeting would be of no value unless Teachers was prepared to agree that Tribune's satisfaction as to its accounting would be a condition of its obligation to draw down the loans.

... The point is simply that Teachers, in conformity with its contract obligations, was asking Tribune to sit down and negotiate in good faith towards agreement on the open points, while Tribune refused to negotiate unless Teachers agreed to add a condition that was outside the scope of the bargain. The existence of open points and the failure of the parties to satisfy the condition of execution of final documentation is, therefore, chargeable to Tribune. It cannot rely on those circumstances to escape its contract obligation. ${ }^{185}$

Finally, the Tribune analysis bears on the general issue of indefiniteness. Classically, indefiniteness was relevant to showing either that the parties had not concluded a deal, or that they had concluded a deal but the terms on which they had agreed gave the courts insufficient purchase for enforcing the deal. Under the Tribune analysis, however, if indefiniteness goes only to the problem of insufficient purchase, the parties will often be bound to negotiate in good faith to resolve the indefinite terms.

c. Cases in which a party's conduct results in the imposition of a duty to negotiate in good faith

In cases like Itek, Channel Home, and Tribune the obligation to negotiate in good faith arises from either an explicit or an implicit commitment in an agreement. The last, and most difficult kind of case is that in which the duty to negotiate in good faith results froin a party's conduct. For exanple, in Budget Marketing, Inc $v$. Centronics Corp, ${ }^{186} \mathrm{BMI}$ and Centronics executed a letter of intent in April 1987, concerning a proposed merger of BMI and Centronics. The letter stated a number of terms of the merger, and four conditions to the merger: (1) Satisfactory completion of

185. Id. at 506 .

186. 927 F.2d 421 (8th Cir. 1991). 
an accounting, legal, and business review of BMI by Centronics; (2) Purchase by BMI of key-man life insurance coverage for its president, Eagle; (3) Avoidance by Centronics of a significant cash outlay for taxes as a result of BMI's planned change in accounting methods; and (4) Execution of a definitive and legally binding agreement. The letter included a specific disclaimer that "this letter shall not be construed as a binding agreement on the part of BMI or Centronics."187

Given this disclaimer, a duty to negotiate in good faith could not have arisen out of the agreement. However, throughout the summer and autumn Centronics gave every indication that the deal was going forward to completion. During this time, and apparently in reliance on these assurances and with Centronic's knowledge, BMI acted in furtherance of the merger. In particular, Eagle, BMI's president, borrowed $\$ 750,000$ for BMI's use, BMI opened additional branch offices and expanded existing branch operations, and BMI purchased key-man life insurance coverage for Eagle. In November, Centronics abruptly halted preparations for the merger, on the ground that as a result of proposed tax legislation and BMI's change in accounting methods, the merger would lead to a cash outlay for taxes, thereby triggering one of the negative conditions of the letter of intent. BMI brought suit, claiming that Centronics' stated reason for terminating negotiations was a pretext, because the proposed tax legislation did not apply to the merger and the change of accounting methods would not have required Centronics to make a cash outlay for taxes.

The court held that no binding commitment to negotiate in good faith could be implied from the letter of intent because of the disclaimer. Nevertheless, the court concluded, "the evidence of Centronics' oral assurances, coupled with BMI's alleged reliance and Centronics' awareness of BMI's reliance, is substantial enough to establish a triable claim under ... promissory estoppel doctrine."188 Other cases have reached a comparable result on the basis of a course of conduct that was engaged in after an agreement that the court considered too indefinite to enforce.

These cases are correct. Where $A$ and $B$ have made an agreement, even one that is not enforceable, $A$ should not encourage $B$ to effectuate the agreement by steps that involve significant costs, or even tease $B$ into taking such steps, unless $A$ is ready to negotiate in good faith to arrive at a final contract. To put this conversely, if $A$ gives such encouragement, or teases $B$ along, $A$ should be put under an obligation to negotiate in good faith. The obligation may be conceived either as contractual, to the extent that $A$ 's conduct can be viewed as giving rise to a tacit commitment, or delictual, to the extent that the obligation is imposed on $A$ as a matter of fairness, as a sort of duty to rescue.

187. Id. at 423 .

188. Id. at 427 . 
Because the obligation in such cases may be conceived as delictual, it may be appropriate to limit damages in such cases to reliance. In the $B M I$ case, the court strongly suggested that if BMI was successful on its claim it might be limited to reliance damages. Other like cases liave taken a comparable position. ${ }^{189}$

\section{CONCLUSION}

The twentieth century witnessed the development of a modern contract law tlat has largely overthrown classical contract law. This overthrow has occurred in two ways. To begin with, in many cases modern contract law has reversed or fundamentally modified the rules of classical contract law. For example, modern contract law has reversed the classical rule that except for some historical anomalies, only bargains were enforceable, and under modern contract law subjective elements play a critical role in the basic principles of contract interpretation.

More important than the overthrow of specific rules of classical contract law, however, has been the overthrow of the deep structure of classical contract law. Where classical contract law employed reasoning that purported to be axiomatic and deductive, modern contract law employs reasoning that is explicitly grounded in social propositions. Where classical contract law had an overriding preference for rules that were objective and standardized, modern contract law has been highly flexible in adopting rules that are individualized and even subjective. Where classical contract law rules were typically binary, modern contract law rules are often multifaceted.

Finally, where classical contract law was largely static, modern contact law is in large part dynamic. So, for example, static rules of interpretation have been replaced by dynamic rules that take into account events before and after the moment of contract formation; the static legal-duty rule has withered almost completely away, to be largely replaced by a dynamic modification regime that takes into account the value of ongoing reciprocity; a static review of liquidated damages provisions is giving way to a dynamic review that takes account of the actual loss; and static offerand-acceptance rules have been replaced by dynamic rules, such as the duty to negotiate in good faith. More generally, as I have shown elsewhere, ${ }^{190}$ modern contract law has in various ways come to grips with the universe of chance in which contracting actually occurs.

The paradigm at the center of classical contract law was a snapshot taken at the moment a bargain was made. In contrast, modern contract law recognizes that contract is a process, so that the picture we see at the time

189 See, e.g., Arcadian Phosphates, Inc. v. Arcadian Corp., 884 F.2d 69 (2d Cir. 1989); Hoffman v. Red Owl Stores, Inc., 133 N.W.2d 287 (Wis. 1965).

190 See generally Eisenberg, Probability and Chance in Contract Law, supra note 45. 
of contract formation, however important, is only one of a series of frames. Unless contract law responds to the whole moving picture, it cannot capture the reality of contract. 